\title{
Proteases and Their Inhibitors in Chronic Obstructive Pulmonary Disease
}

\author{
Tapan Dey ${ }^{1,2}$ (D) , Jatin Kalita ${ }^{1}$, Sinéad Weldon ${ }^{3}$ (i) and Clifford C. Taggart ${ }^{3, *}$ \\ 1 Biological Sciences and Technology Division, CSIR-North East Institute of Science and Technology, \\ Jorhat 785006, Assam, India; rs_tapandey@dibru.ac.in (T.D.); kalitajk74@gmail.com (J.K.) \\ 2 Centre for Biotechnology and Bioinformatics, Dibrugarh University, Dibrugarh 786004, Assam, India \\ 3 Airway Innate Immunity Research Group, Centre for Experimental Medicine, School of Medicine, \\ Dentistry and Biomedical Sciences, Queen's University Belfast, Belfast, Northern Ireland BT9 7BL, UK; \\ s.weldon@qub.ac.uk \\ * Correspondence: c.taggart@qub.ac.uk; Tel.: +44-28-9024-5133
}

Received: 30 July 2018; Accepted: 25 August 2018; Published: 28 August 2018

\begin{abstract}
In the context of respiratory disease, chronic obstructive pulmonary disease (COPD) is the leading cause of mortality worldwide. Despite much development in the area of drug development, currently there are no effective medicines available for the treatment of this disease. An imbalance in the protease: Antiprotease ratio in the COPD lung remains an important aspect of COPD pathophysiology and several studies have shown the efficacy of antiprotease therapy in both in vitro and in vivo COPD models. However more in-depth studies will be required to validate the efficacy of lead drug molecules targeting these proteases. This review discusses the current status of protease-directed drugs used for treating COPD and explores the future prospects of utilizing the potential of antiprotease-based therapeutics as a treatment for this disease.
\end{abstract}

Keywords: chronic obstructive pulmonary disease; protease; antiprotease

\section{Introduction}

Chronic obstructive pulmonary disease (COPD) is considered to be one of the major diseases of modern times. With a continuous rise in pollution across the globe, combined with continued cigarette smoking in both developing and developed countries, COPD is set to become the third leading cause of death by $2030[1,2]$. Despite major efforts to find a treatment for COPD, effective therapeutic strategies remain elusive [3-7]. COPD is a progressive lower respiratory tract disorder encompassing chronic bronchitis and emphysema. Chronic bronchitis is caused by increased secretion of mucus from differentiating goblet cells leading to a thicker mucus layer lining the airways [8]. Emphysema is caused by the destruction of the terminal bronchioles leading to decreased gas exchange in the lower airways [9]. Both diseases result in decreased pulmonary function and quality of life. Cigarette smoking is considered the primary cause of COPD, although only $15-20 \%$ of smokers are thought to develop COPD. This fact can be rationalized by the fact that around $90 \%$ of COPD cases are either ex-smokers or current smokers $[10,11]$. Moreover, around 1-5\% of COPD cases have an underlying genetic component caused by a deficiency of the serum glycoprotein $\alpha-1$ antitrypsin (A1AT) $[12,13]$. A1AT is the primary serine antiprotease responsible for protecting the lungs against the actions of neutrophil-derived serine proteases.

COPD is also considered to be an age-related disorder [14,15]. Therefore, with an increase in the worldwide aging population, the number of patients being diagnosed with COPD is also on the increase. Presently, bronchodilators are the mainstay treatment for the management of COPD but fall short of overall effectiveness [16-18]. In addition to environmental insults such as cigarette smoke, bacterial 
and viral pathogens may also play a major role in the development of COPD and contribute to the rise in exacerbation frequency among the COPD population [19-21]. Given the increasing healthcare and societal burden associated with the increase in COPD, a number of therapeutic programmes are ongoing to develop strategies for the treatment of COPD [22-30]. As it will be beyond the scope of this review to discuss all of the ongoing therapeutic programmes, we will focus on the current status of antiprotease therapy against COPD.

\section{Proteases Involved in COPD Pathophysiology}

The protease: Antiprotease imbalance is considered to be one of the core physiological mechanisms involved in the pathogenesis of COPD [31]. One of the major genetic causes of COPD is A1AT deficiency [32]. A1AT is a serine protease inhibitor which regulates the neutrophilic chemotaxis involving both CXCR1 and FC $\gamma$ RIIIb signaling [33]. In addition, A1AT has also been shown to regulate the levels of cathepsin B and metalloproteinase-2 (MMP2) in A1AT deficient patients treated with A1AT augmentation therapy [34].

There are four different types of proteases namely serine, cysteine, aspartic, and MMPs which are thought to be involved in the pathogenesis of COPD. Among serine proteases, specifically, neutrophil elastase (NE), dipeptidyl peptidase 4, cathepsin G, proteinase 3, cathepsin C, mast cell-derived tryptase and chymase are found to be associated with the severity of COPD [35-40]. The metal-activated proteinases including MMP-2, MMP-8, MMP-9, MMP-12, and MMP-13 are found to be highly expressed in both in vivo models and clinical samples [41-46]. The cysteine proteases including caspase-1, caspase-3, caspase-7, caspase-8, caspase-9, caspase-11, cathepsin $K$, and cathepsin $S$ have also been shown to be up-regulated in COPD patients [47-55]. Finally, elevated levels of the aspartic proteases cathepsin $\mathrm{D}$ and cathepsin $\mathrm{E}$ have been demonstrated in COPD patient tissue and various COPD models [56-59].

\section{The Role of Serine Proteases and Their Inhibitors in COPD}

\subsection{Neutrophil Elastase (NE)}

Neutrophil Elastase (NE) is the primary enzyme present in azurophil granules in the neutrophil cytoplasm and is thought to play a role in the proteolytic breakdown of phagocytosed molecules. Neutrophils are the first cell type to arrive in the lung following stimulation by microbial pathogens, smoking, and various other environmental exposures [60]. However, unopposed NE activity in the lung may lead to lung parenchyma destruction and subsequent increased production of inflammatory mediators [61]. A1AT is considered to be the primary regulator of NE activity. In normal lungs, A1AT accounts for around $90 \%$ of anti-NE activity at the lower respiratory tract providing protection to the underlying connective tissues [62]. Elevated serum levels of NE have been found to be associated with COPD severity [63]. In addition, higher NE concentrations exist in saliva and exhaled breath condensate of COPD patients $[64,65]$. Therefore several previous studies have focused on the inhibition of NE as a treatment strategy for COPD.

MR899 was the first NE inhibitor used in clinical trials for COPD (Figures 1 and 2) [66]. MR899 is a cyclic thiol compound derived from homocysteine lactone and thiolactic acid. It was found to be a competitive and reversible NE inhibitor. Oral administration of MR899 at a dose of $500 \mathrm{mg}$ twice a day for 4 weeks was tested to check its efficacy in reducing levels of lung destruction markers. In this study, urinary levels of desmosine and plasma elastin-derived peptides thought to be derived from NE activity were measured. Interestingly, MR899 was found to be effective only in those COPD patients who had only recently been diagnosed with COPD and who had less established disease.

FR901277 is a cyclic peptide lactone isolated from the fermentation broth of Streptomyces resistomycificus. FR901277 was shown to be effective in reducing porcine pancreatic elastase (PPE)-induced emphysema in hamsters (Figures 1 and 2). The median effective dose at around $8 \mathrm{mg} / \mathrm{kg}$ body weight by intratracheal instillation effectively inhibited the increase observed in lung 
compliance and vital capacity of the lungs after 2 weeks of PPE treatment. However, despite these promising studies follow-up studies using FR901277 have not been carried out. ONO-6818 was found to effectively reduce the lung hemorrhage and neutrophil accumulation associated with NE-induced rat emphysema model (Figures 1 and 2) [67]. Oral pre-administration of ONO-6818 at a dose of $100 \mathrm{mg} / \mathrm{kg}$ was found to reduce increased hemoglobin concentration as well as neutrophil count and myeloperoxidase activity in bronchoalveolar lavage (BAL) fluid within $6 \mathrm{~h}$ of human NE instillation. In addition, histopathology studies demonstrated a decrease in emphysematous changes in the ONO-6818 treated group. Furthermore, ONO-6818 was shown to reduce NE-induced increases in lung compliance and mean linear intercept $\left(\mathrm{L}_{\mathrm{m}}\right)$ in the rat model. However, despite these promising results ONO-6818 was later shown to have a deleterious effect on liver function.

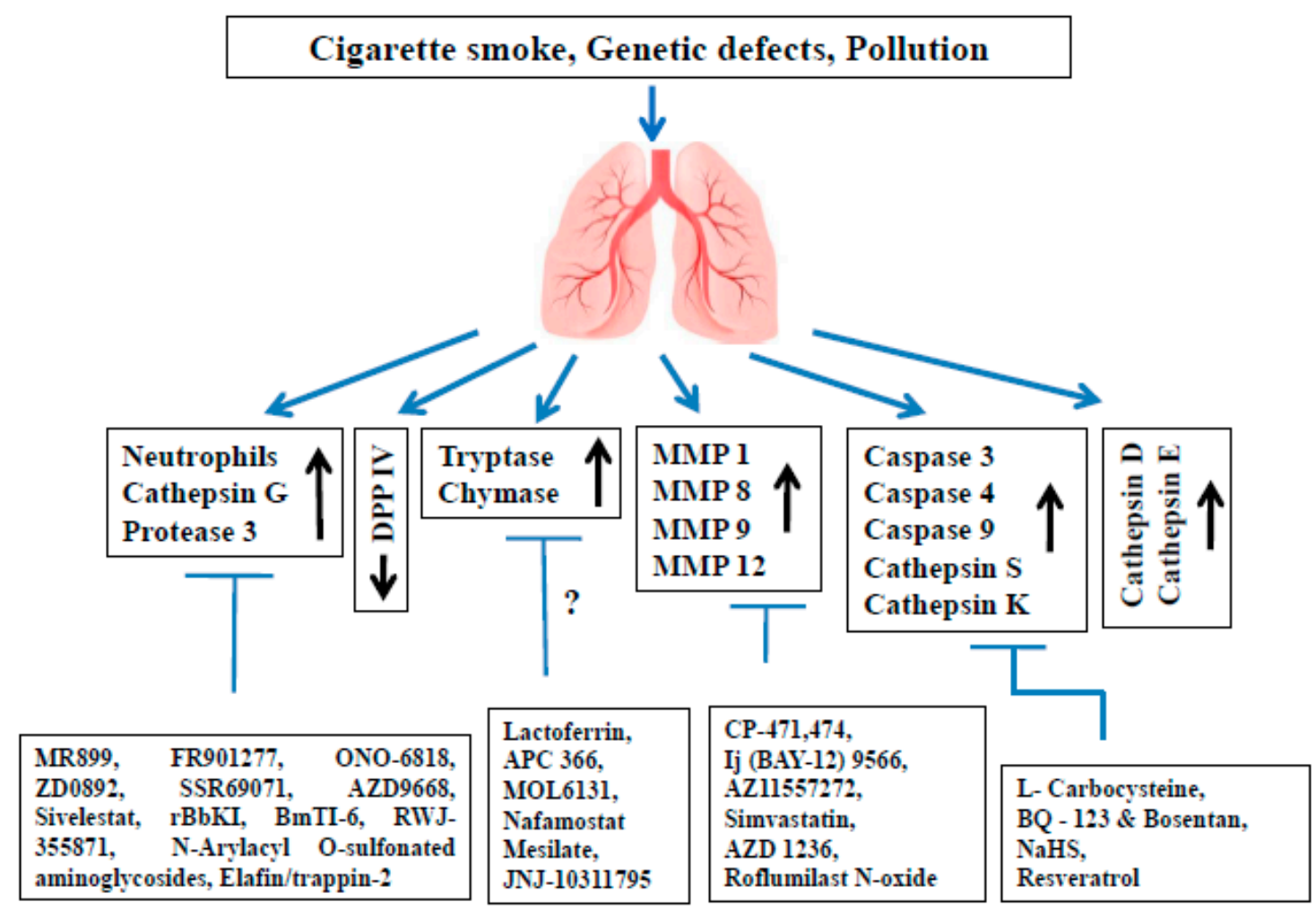

Figure 1. Present status of different protease inhibitors tested against COPD models. COPD: Chronic obstructive pulmonary disease; DPP IV: Dipeptidyl peptidase IV; MMP: Matrix metalloproteinase.

In another study, the specific NE inhibitor, ZD0892, was shown to have a profound effect in both the acute and chronic phase emphysema guinea pig models (Figures 1 and 2) [68]. Oral administration of ZD0892 at a dose range of 3-30 mg/ $\mathrm{kg}$ resulted in lower total neutrophil cell counts in BAL fluid in a dose-dependent manner. Moreover, it lowered the levels of desmosine and hydroxyproline in BAL fluid. In addition, the expression of inflammatory mediators such as macrophage inflammatory protein 2 (MIP-2), monocyte chemoattractant protein 1 (MCP-1) and tumor necrosis factor- $\alpha$ (TNF- $\alpha$ ) were also found to be reduced upon ZD0892 administration. More importantly, ZD0892 was also found to effectively reduce inflammation in chronic smoke exposed guinea pigs. Interestingly SSR69071, a saccharide derivative was found to be more potent than earlier tested NE inhibitors [69]. SSR69071, when orally pre-administrated at a dose range of 0.3 to $30 \mathrm{mg} / \mathrm{kg}$ body weight before elastase instillation, was shown to effectively reduce elastase-induced lung hemorrhage in mice. SSR69071 was also shown to decrease lung hemorrhage and lung injury. 


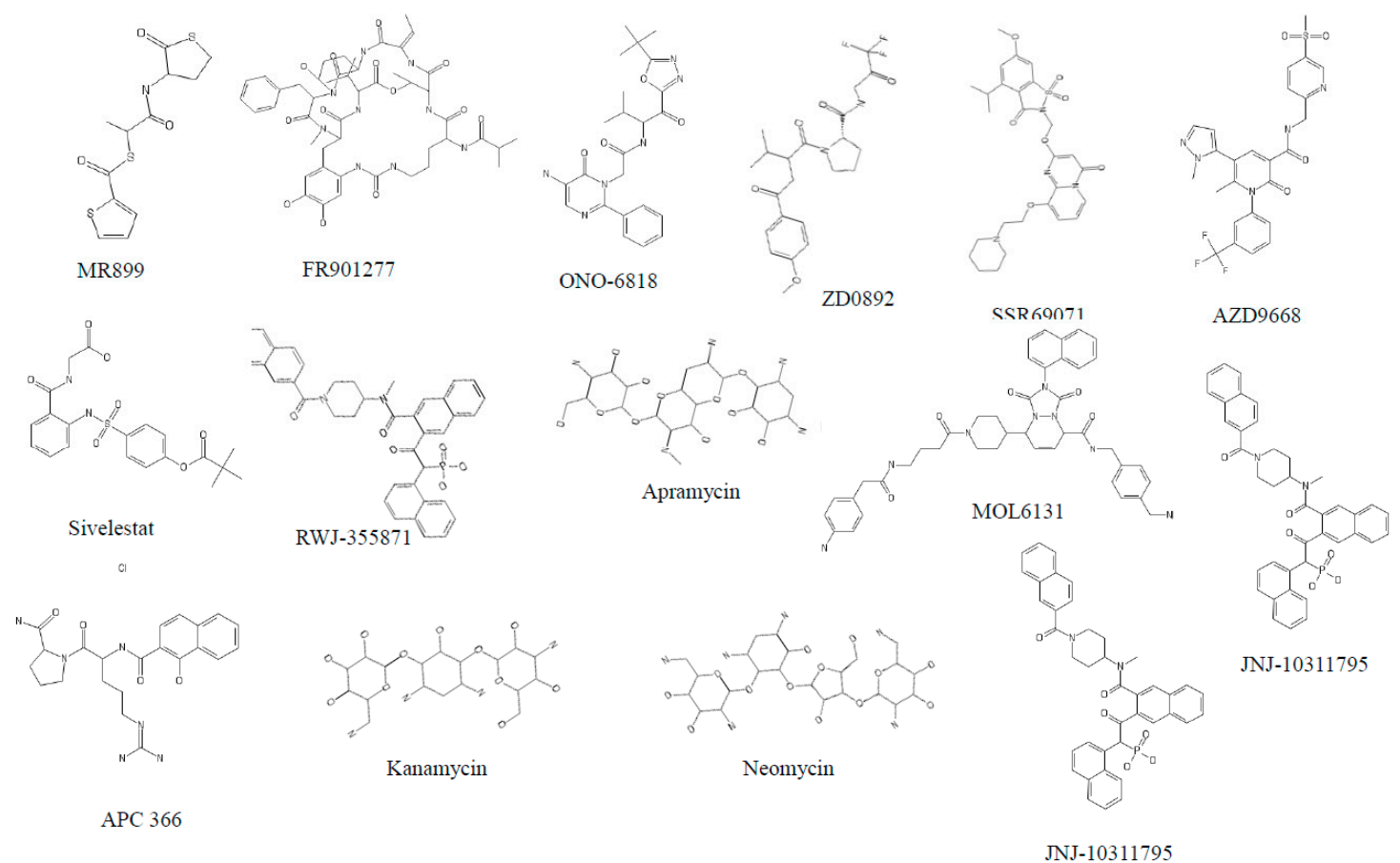

Figure 2. Structure of different serine protease inhibitors tested against COPD models.

Preclinical studies with AZD9668, an orally available NE inhibitor has found it to be effective against both human NE- and cigarette smoke-induced emphysema models (Figures 1 and 2) [70]. Affinity studies with AZD9668 have shown it to bind NE more rapidly compared to ONO-6818. Moreover, it showed more specificity for NE compared to other NE inhibitors such as ONO-6818 and sivelestat. In an acute NE instilled model, AZD9668 was shown to effectively reduce BAL hemoglobin level at a dose of $>1.5 \mathrm{mg} / \mathrm{kg}$ and BAL hydroxyproline and desmosine levels at a dose of $2.5 \mathrm{mg} / \mathrm{kg}$ and $10 \mathrm{mg} / \mathrm{kg}$, respectively. In a chronic smoke-induced emphysema mouse model, AZD9668 was shown to effectively reduce BAL neutrophil levels at a dose of $6 \mathrm{mg} / \mathrm{kg}$ and BAL IL-1 $\beta$ level at a dose of $1 \mathrm{mg} / \mathrm{kg}$ body weight. Moreover, AZD9668 was shown to completely prevent airspace enlargement (emphysema) and small airway remodeling in chronic models. Although AZD9668 was shown to be effective in preclinical models, it was shown to be ineffective in clinical trials of COPD. In a randomized, placebo-controlled phase IIb trial, three months treatment with AZD9668 improved neither the lung function nor the sign and symptoms associated with COPD patients with a history of budesonide/formoterol therapy [71]. In another clinical trial in COPD patients, AZD9668 at a dose of $60 \mathrm{mg}$ twice a day did not reduce inflammation or lung damage when applied in combination with tiotropium [72].

In addition to synthetic protease inhibitors, plant-derived protease inhibitors have been evaluated. Bauhinia bauhinioides L., a plant from the Caesalpinioideae sub-family has been shown to secrete many protease inhibitors. Among them, Bauhinia bauhinioides Kallikrein proteinase Inhibitor [73] (rBbKI) and Bauhinia bauhinioide scruzipain inhibitor [74] (BbCI) have been found to effectively ameliorate elastase-induced emphysema (Figure 1). In a model of elastase-induced emphysema model, rBbKI was shown to effectively reduce elastase-induced inflammation and extracellular matrix remodeling. Moreover, rBbKI reduced the number of BAL cells and inflammatory markers including TNF- $\alpha$, lung remodeling markers (MMP-9, MMP-12, and TIMP-1), and oxidative stress markers (eNOS and iNOS) markers in respiratory airways and alveolar walls. In addition, rBbKI diminished the increase in lung mechanical stress parameters such as respiratory system elastance, respiratory system resistance, airway resistance, lung tissue elastance and lung tissue damping. BbCI was also shown to effectively ameliorate lung inflammation and extracellular lung remodeling at a dose of $2 \mathrm{mg} / \mathrm{kg}$. 
Recently, the potency of an arthropod-derived serine protease inhibitor in the elastase-induced emphysema model was evaluated [75]. In the study, the authors employed BmTI-6, a Kunitz-type serine protease inhibitor to test its efficacy against elastase-induced emphysema model (Figure 1). The lung $\mathrm{L}_{m}$ was found to be reduced in the recombinant BmTI-6-D1 *(Domain 1) treated group. In addition, the BmTI-6-D1 instillation reduced the respiratory mechanics and the macrophages, neutrophil and lymphocyte count in BAL fluid. Moreover, it increased the volume proportion of collagen and elastic fibers and decreased NE activity compared to the elastase only treated group.

\subsection{Cathepsin $G$ (cat $G$ )}

Cathepsin $G$ (cat $G$ ) is one of the three major serine proteases secreted by the azurophilic granules of neutrophils [76]. In addition to its antibacterial activity, cat $G$ plays a role in innate immunity, chemoattraction and extracellular matrix degradation $[77,78]$. Cat $G$ was found to protect against Streptococcus pneumoniae-induced lung damage [79]. In contrast, genetic knockdown of cat $G$ has also been found to protect lung tissue destruction from long-term exposure of cigarette smoke [37]. Moreover, increased expression of cat $\mathrm{G}$ can lead to alveolar wall destruction and abnormal secretion of mucus from the airway serous cells in COPD patients [80-82].

Garavilla et al. described the cat G inhibitory activity of RWJ-355871 in lipopolysaccharide (LPS)-induced acute inflammation model (Figures 1 and 2) [83]. Upon aerosolized instillation of RWJ-355871, levels of exhaled nitric oxide were reduced by $20-37 \%$ in this model. In addition, neutrophil, lymphocyte, monocyte, eosinophil, and basophil counts in BAL among in the RWJ-355871 treated group were found to be significantly reduced compared to control groups. In another set of experiments, by the same group, RWJ-355781 treatment did not reduce the total cell count in the BAL of treated animals, however, it reduced the neutrophilic load by $66 \%$ in the smoke-induced inflammation model [84]. In addition, RWJ-355781 instillation reduced the levels of keratinocyte-derived chemokine (KC), a murine homolog of IL-8, in a smoke-induced acute inflammation model. These studies demonstrate the efficacy of RWJ-355781 in acute inflammation models. However, in-depth studies in chronic lung models are required in order to establish the potential of RWJ-35578 for the treatment of chronic lung inflammation associated with COPD. Recent studies by Cracian et al. demonstrated the potential of N-Arylacyl O-sulfonated aminoglycosides for cat $\mathrm{G}$ inhibition in in vitro models [85]. The aminoglycoside derivatives of neomycin, kanamycin, and apramycin showed significant inhibition of cat $\mathrm{G}$ at $\mathrm{IC}_{50}$ doses ranging from 0.42 to $209 \mu \mathrm{M}$. However, further in vivo studies will be required to determine the therapeutic potential of these aminoglycosides for the treatment of COPD.

\subsection{Proteinase 3 (PR3)}

Proteinase 3 (PR3) is the most abundant serine protease present in the azurophilic granules of neutrophils [86] and is mostly active in the immune response to infection and is an autoantigen in Wegeners' disease [87]. In addition, it possesses antibacterial activity against a host of pathogens such as Pseudomonas aeruginosa, Staphylococcus aureus, Aspergillus fumigatus, and Candida albicans [88]. As degranulation-associated neutrophilic inflammation was found to play a major role in COPD pathophysiology, PR3 has also received attention with regard to its potential role in inflammation. PR3 also takes part in various pro-inflammatory responses such as activation of TNF- $\alpha$ and IL-1 $\beta$ [89]. The PR3 concentration as well its activity was found to be up-regulated during exacerbations in COPD in contrast to the levels found in stable COPD patients [90]. In addition, mice deficient in PR3 were significantly protected from lung tissue destruction after long-term cigarette smoke exposure for 6 months [37]. These studies suggest a role for PR3 in COPD pathophysiology.

Elafin/trappin-2, an innate serine protease inhibitor primarily secreted by epithelial cells, was found to regulate PR3 activity (Figures 1 and 2). In the PPE-induced emphysema model, trappin-2 reduced lung neutrophil accumulation within $24 \mathrm{~h}$ of intranasal administration [91]. An engineered trappin-2, trappin-2 A62L, decreased PR3 induced pro-inflammatory cytokines such as IL-6 and IL-8 by lung cells [92]. In addition, the engineered NE-resistant variants, GG- and QQ-elafin, showed prominent anti-inflammatory 
activity compared to WT-elafin. The GG-elafin variant was shown to reduce inflammation in both LPS challenged in vitro and acute in vivo lung inflammation models [93]. In a yet another study of elastase-induced emphysema, WT-elafin was shown to protect against lung destruction and prevent neutrophil alveolitis [94].

In addition to innate inhibitors, several types of synthetic PR3 inhibitors have been evaluated for their efficacy. Among them, kanamycin derived $\mathrm{N}$-arylacyl O-sulfonated aminoglycoside, KanCbz, has been shown to have the most potent $\mathrm{IC}_{50}(16 \mu \mathrm{M})$ against PR3 compared to other tested derivatives (Figures 1 and 2) [85]. Though a large number of studies have shown anti-inflammatory properties of elafin, there was no clinical evaluation of this inhibitor in COPD. Therefore, clinical trials with elafin or its functional variants may be an interesting future treatment option for COPD.

\subsection{Dipeptidyl Peptidase IV (DPP IV)}

DPP IV, commonly known as cluster of differentiation 26 (CD26), is a cell surface serine protease which primarily cleaves X-proline or X-alanine dipeptides from the $\mathrm{N}$-terminus of polypeptides [78]. DPP IV is expressed both as a type II transmembrane protein and in soluble form $[95,96]$. Pertaining to its ubiquitous in nature, it is also found in the respiratory tract in the lung parenchyma (type I and II cells), interstitium and in alveolar macrophages and mononuclear lymphoid cells [97].

Decreased serum levels of DPP IV were found to be associated with COPD pathogenesis, independent of age and smoking history [36,98]. More importantly, elevated levels of DPP IV was also associated with acute exacerbation in COPD patients [36]. Interestingly, the lung tissue of smokers and end-stage COPD patients were demonstrated to have higher expression of DPP IV than non-smoker tissue [99]. Moreover, immunostaining studies on airway epithelia, pleural mesothelia, and alveolar macrophages of COPD patients were shown to have enhanced expression of DPP IV [97]. Owing to its neutrophil chemorepellant nature, DPP IV may serve as an augmentation therapy for COPD. Several lines of evidence have shown that soluble recombinant DPP IV may have important anti-inflammatory effects [100-102]. Herlihy et al. showed that recombinant human DPPIV treatment $(2 \mu \mathrm{g} / \mathrm{mL})$ reduced neutrophil infiltration in a type II collagen-induced lung inflammation model [100]. In addition, DPP IV was also found to regulate C-X-C motif chemokine 12 (CXCL12), which primarily activates the inflammatory cascade stimulated by inflammatory stimuli such as LPS [101]. The release of DPP IV from the cell membrane into the circulation may be important in COPD pathogenesis. MMPs were found to be associated with the release of DPP IV from the cell membrane [103]. As elevated levels of a number of MMPs were also found to be associated with COPD, this may represent a mechanism to explain elevated levels of DPP IV in COPD.

\subsection{Tryptases}

Tryptases are tetrameric serine proteases secreted by mast cells [104]. They are the most abundant form of serine proteases secreted by mast cells during anaphylactic shock [105]. There are two types of tryptases, namely, $\alpha$-tryptase and $\beta$-tryptase [106]. In addition to its active role in allergic reactions, tryptases have also been found to be associated with smoking-related chronic lung diseases. An increase in tryptase levels was found in the BAL of smokers [107]. Several studies have shown apositive correlation between peripheral airway tryptase positive cells and lung function $\left(\mathrm{FEV}_{1} / \mathrm{VC}\right)$ in patients with COPD indicating a possible role for tryptases in this disease [40,108]. In contrast, tryptase levels were found to be lower in subepithelial layer of central airways of COPD patients and not found to correlate with lung function [109]. In addition to its high cell count, the level of tryptase activity was found to be elevated (3.4 times) in patients with severe COPD compared to mild COPD patients [110]. Although a number of tryptase inhibitors such as lactoferrin, APC 366, MOL 6131, and nafamostat mesilate have been used to study the underlying signaling mechanisms in allergic induced airway disease models [111-114], a study pertaining to COPD pathophysiology is yet to be carried out (Figure 1). Thus, pre-clinical studies to evaluate tryptase inhibitors in COPD models maybe useful to delineate further a role for this protease in COPD. 


\subsection{Chymases}

Chymases are serine proteases secreted by the mast cells and possess cathepsin G-like specificity [115]. The primary function of chymases is the conversion of angiotensin-I to angiotensin-II. Excessive leakage of chymase due to higher mast cell degranulation by different stimulants leads to cellular matrix degradation, activation of TGF- $\beta$ /Smad signaling, conversion of active MMPs from their zymogen form, and activation of several interleukins (such as IL-1 $\beta$, IL-18, etc.) and endothelins [116-118]. There are basically two types of chymases: $\alpha$-chymases and $\beta$-chymases. The chymases present in humans are $\alpha$-class whereas rodents possess $\beta$-chymases in addition to $\alpha$-chymases [119]. In addition to their role in vascular diseases, chymases were also found to be associated with lung diseases such as pulmonary fibrosis, pulmonary arterial hypertension (PAH), asthma, and COPD [116,120-122]. Several investigators have shown a higher number of chymase-positive cells in lung specimens of COPD patients $[40,121]$. Specifically, the numbers of chymase-positive cells were found to be higher in peripheral airway cells as compared to central airways. In addition, the numbers of chymase-positive cells were found to be positively correlated with $\mathrm{FEV}_{1} \%$ predicted among the COPD patients [121]. Moreover, chymase was shown to stimulate mucin production by the human bronchial epithelial cells [123]. Therefore, inhibition of chymases may be of interest in COPD treatment.

Many investigators have shown that inhibition of chymase has a profound effect on vascular remodeling, PAH, and atherosclerosis. Chymase inhibitors like BAY 1142524, RO5066852, TY-51469, JNJ-10311795, and many others have been tested in PF, atherosclerosis, and inflammation (Figures 1 and 2) $[83,124-126]$ but studies relating to their effect on COPD have been very limited. De Garavilla et al. provided the first evidence of the anti-inflammatory effect of chymase inhibitor JNJ-10311795 against LPS-induced airway inflammation [83]. The JNJ-10311795 inhibitor was shown to reduce inflammatory mediators within $24 \mathrm{~h}$ of LPS instillation. However, because of its low oral bioavailability $(<1 \%)$ and low plasma half-life in rats, the aerosolized administration was postulated to be a more effective way of treating airway inflammation. In another study, JNJ-10311795 exhibited anti-inflammatory properties in a smoke-induced airway inflammation model [84]. Therefore, it will be very useful to study the anti-inflammatory effect of chymase inhibitors in COPD models to dissect the underlying mechanisms and may provide an alternative therapeutic target for COPD treatment in the near future.

\section{The Role of MMPs and Their Inhibitors in COPD}

MMPs are zinc- and calcium-dependent endopeptidases responsible for extracellular matrix remodeling [127]. There are more than 20 MMPs believed to be involved in various pathological conditions including inflammation. On the basis of substrate specificity, MMPs are classified as collagenases, gelatinases, stromelysins, elastases and membrane-bound proteinases [128]. In addition to transcriptional activation and post-transcriptional modifications, the functional activities of MMPs were also found to be regulated by the TIMPs [129].

Several investigators, through both in vitro and in vivo studies, have validated the role of MMPs in emphysema pathophysiology [28,130-133]. Thus, many studies have been undertaken to study the effect of both specific and broad-spectrum MMP inhibitors for emphysema treatment. Among them, the first randomized, double-blind study was undertaken by Salmen et al. [134] who tested the efficacy of a broad spectrum MMP inhibitor, CP-471,474, in a cigarette smoke-induced emphysema model in guinea pigs (Figure 1). CP-471,474 reduced the level of MMP-1 within 2 months after smoke exposure. Moreover, it reduced the alveolar size and destruction of lung parenchyma as compared to smoke-treated guinea pigs. In another set of experiments, Pemberton et al. tested the efficacy of the inhaled MMP inhibitor, ilomastat, in a chronic smoke-exposed mouse model (Figures 1 and 3). Ilomastat reduced lavage neutrophil and macrophage counts at the 6-month time point [135]. In addition, it also reduced the airspace size as compared to smoke-exposed animals alone. Ma et al. synthesized a substituted $\gamma$-Keto carboxylic acid (1j) from BAY 12-9566, a selective inhibitor of MMP-12, and tested its efficacy against a PPE-induced emphysema model (Figures 1 and 3) [136]. This inhibitor 
reduced elastase-induced increase in lung wet weights, and morphometric analysis also showed that it protected alveolar septal walls and elastic fibres from proteolytic cleavage. Moreover, the histological data showed that it also protected the lung against hemorrhage induced by cigarette smoke exposure. On the other hand, a dual inhibitor of MMP-9/MMP-12 and AZ11557272, protected mice against an increase in small airway thickness and increases in total lung capacity, residual volume and vital capacity in smoke-exposed guinea pigs (Figures 1 and 3) [137]. However, a clinical, randomized, double-blind, placebo-controlled study with selective MMP-9 and MMP-12 inhibitor, AZD1236, did not yield any significant effect in reducing symptoms associated with moderate /severe COPD [138].

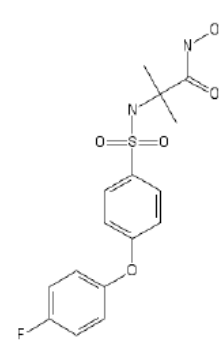

CP- 471,474

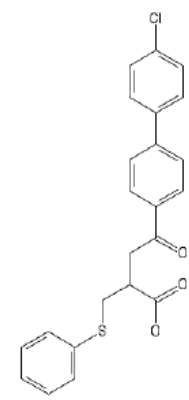

BAY-12- 9566

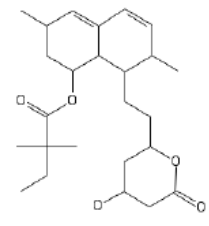

Simvastatin

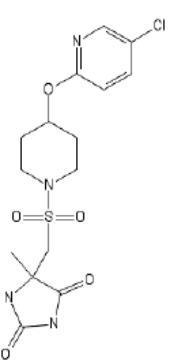

AZD 1236

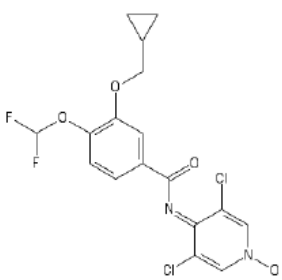

Roflumilast N-oxide

Figure 3. Structure of different matrix metalloprotease inhibitors tested against COPD models.

Simvastatin, a lipid-lowering medication was found to effectively reduce the emphysematous changes in murine models (Figures 1 and 3) $[139,140]$. Simvastatin reduced changes in the $\mathrm{L}_{\mathrm{m}}$ of lung and lung destruction significantly in smoke-treated mice. In addition, simvastatin reduced MMP-8 and MMP-9 activity in this model (139). Further, clinical studies with salmeterol/fluticasone significantly reduced the levels of IL-8 and MMP-9 in sputum samples of treated COPD patients [141].

These studies indicate the importance of MMP inhibition in reducing emphysema in rodent models of COPD. However, few clinical studies have been performed looking directly at MMP inhibition, due to the off-target effects of some of these inhibitors. Therefore, the development of more refined and specific MMP inhibitors will be necessary for future development for the treatment of COPD.

\section{The Role of Cysteine Proteases and Their Inhibitors in COPD}

\subsection{Caspases}

Although the protease: Antiprotease imbalance theory is considered to be an important mechanism underlying emphysema development, other mechanisms may explain pathological changes associated with the development of emphysema [142,143]. The vascular theory envisages the chronic loss of both epithelium and endothelium cells of the lung due to altered programmed cell death. Aoshiba et al. showed that a single intratracheal injection of active caspase- 3 into the mouse lung could induce emphysematous changes [144]. These results were further validated by Yokohori, et al. through clinical studies in patients with emphysema [145]. They showed that the percentage of alveolar wall cells undergoing apoptosis and the total number of alveolar wall cells undergoing proliferation was higher in emphysema patients compared to healthy smokers and non-smokers. Further, emphysematous lungs exhibited other signs of apoptosis such as DNA fragmentation, the presence of active caspase-3, Bad, Bax, and fragmented poly (ADP-Ribose) polymerase in lung homogenate $[48,146,147]$. These increases in apoptosis were mediated by a variety of inflammatory mediators including the IL-1 receptor, IL-18 receptor- $\alpha$, P2X7 receptor, endothelin-1 receptor, and the NLRP3 inflammasome $[47,53,148-150]$. 
L-Carbocysteine, a well-known mucolytic agent, was shown to inhibit hydrogen peroxide-mediated caspase-3 and caspase-9 activation through Akt phosphorylation in airway epithelial cells [151]. Moreover, carbocysteine also reduced the airspace enlargement and alveolar destruction of rat lungs exposed to cigarette smoke and lowered the mRNA expression of caspase- 3 in the lung parenchyma of this model (Figures 1 and 4) [152]. Administration of BQ-123 and bosentan, both endothelin-1 antagonists, for 21 days reduced smoke-induced increases in both $\mathrm{L}_{m}$ and destructive index in lung tissue (Figure 1). In addition, it also lowered the distribution of caspase-3 positive cells as well as caspase- 3 mRNA expression in lung tissue [150]. Intraperitoneal injection of hydrogen sulfide $\left(\mathrm{H}_{2} \mathrm{~S}\right)$ donor sodium hydrosulfide (NaHS) in a smoke-induced emphysema model inhibited smoke-induced oxidative stress, caspase-3 activation and emphysema in mouse lungs (Figures 1 and 4) [153]. Moreover, it attenuated the TNF- $\alpha$ levels, neutrophil, and monocyte counts and decreased smoke-induced bronchial wall thickness. In an in-depth in vitro study, resveratrol was showed to protect bronchial epithelial cells from smoke-mediated apoptosis by attenuating the expression of caspase-3 and caspase-4 (Figures 1 and 4) [154]. These studies provide evidence for targeting caspase-mediated apoptotic pathways in order to ameliorate emphysema development. However, the basic understanding of underlying mechanisms behind the role of apoptosis in emphysema pathogenesis is still in its infancy and further work needs to be done to translate these findings to the clinic.

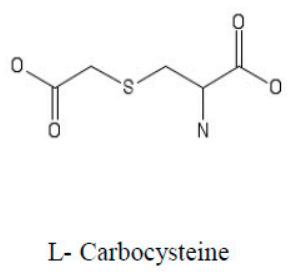

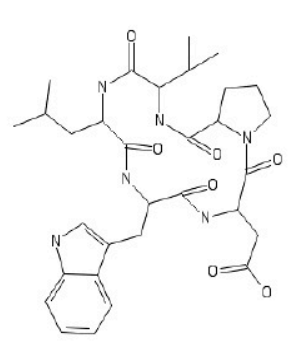

BQ -123

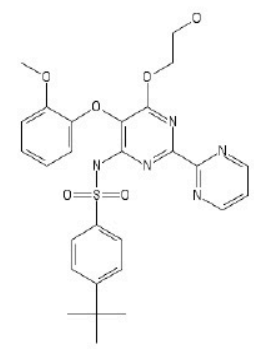

Bosentan

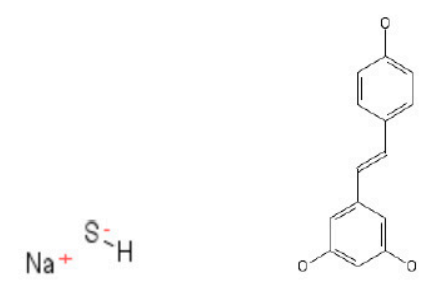

$\mathrm{NaHS}$

Resveratrol

Figure 4. Structure of different cysteine protease inhibitors tested against COPD models.

\subsection{Cathepsin $S$ (cat $S$ )}

Cathepsin S (cat S) is an elastolytic cysteine protease with both intracellular and extracellular activities including tissue remodeling [55]. Recent studies have shown an increased level of serum cat $S$ in COPD patients which were inversely correlated with severe airway limitation [55]. Zheng et al. showed that IFN- $\gamma$ is a potent stimulator of cat $S$ and selective inhibition of cat $S$ attenuates the IFN- $\gamma$ induced DNA damage, emphysema, and apoptosis in murine models [155]. Increased numbers of CD8+ T lymphocytes in peripheral airways was found to be associated with COPD [156-158]. In addition, the CD8+ cell count in the bronchial biopsies has also been found to be inversely correlated with lung function $\left(\mathrm{FEV}_{1}\right)$ in chronic bronchitis $(\mathrm{CB})$ patients [159]. More in-depth studies reveal that IFN- $\gamma$, a crucial product of CD8+ T lymphocytes, was linked with alveolar enlargement, neutrophilic inflammation and enhanced complications underlying emphysema with concomitant induction and activation of various cathepsins and MMPs [160]. Selective inhibition and genetic knockdown studies of cat $\mathrm{S}$ further illustrated the underlying mechanism behind IFN- $\gamma$ induced emphysema pathophysiology [155].

Interestingly, secretory leukocyte protease inhibitor (SLPI), which is predominantly secreted at airway mucosal surfaces during inflammation, decreased IFN- $\gamma$ induced cat $S$ expression [161]. Geraghty et al. showed that the SLPI inhibited IFN- $\gamma$ induced IкB $\beta$ degradation and subsequently reduced cat $S$ expression in macrophages (Figure 1) [161]. Although there is some evidence that cat $S$ may play a role in COPD pathophysiology, no clinical trials directed towards this protease has been conducted so far. Moreover, studies with COPD genetic models will provide more validation to the use of anti-cat $\mathrm{S}$ therapy for COPD treatment. 


\subsection{Cathepsin K (cat K)}

Cathepsin $\mathrm{K}$ (cat K), a lysosomal cysteine protease, was found to be secreted by lung epithelial cells [162]. Although the role of cat $\mathrm{K}$ is well known in lung fibrosis, very little is known about its potential role in COPD. Only one study has demonstrated increased expression of cat $\mathrm{K}$ in lung homogenates of COPD patients [54]. In addition, they showed that chronic smoke exposure significantly increased cat $\mathrm{K}$ expression by alveolar macrophages.

\section{The Role of Aspartic Proteases and Their Inhibitors in COPD}

\subsection{Cathepsin D (cat D)}

Cathepsin D (cat D) is an aspartyl endopeptidase primarily involved in the degradation of proteins in lysosomal compartments [163]. In addition, it plays an important role in antigen processing, cell proliferation, and activation of various bioactive protein precursors [164,165]. Moreover, cat D has also been found to be associated with emphysema [160]. Similar to the activation mechanism (described earlier), IFN- $\gamma$ plays an important role in the induction and activation of cat D [166]. Moreover, an increased expression of cat D localized primarily in macrophages was observed in a smoke-exposed murine model [56]. However, the scientific knowledge in the area of cat D mediated emphysema pathogenesis is very limited to date.

\subsection{Cathepsin E (cat E)}

Cathepsin E (cat E), a major intracellular non-lysosomal aspartyl protease, plays an important role in antigen processing [167]. cat $\mathrm{E}$ was found to be mainly associated with different types of cancer [168-170]. Elevated expression of cat $\mathrm{E}$ is associated with airflow limitation in COPD patients $[58,59]$ and found to be inversely correlated with $\mathrm{FEV}_{1} \%$ predicted in COPD patients. Upon deciphering the underlying mechanism behind increased expression of cat $\mathrm{E}$ in COPD, it was revealed that it mediates the increased expression of mitochondrial fission protein dynamin-related protein 1 and activates the caspase-dependent apoptosis pathway leading to parenchymal destruction in smoke-exposed murine models [59]. Although there is limited information available linking cat E expression and COPD pathogenesis, more in-depth mechanistic studies are required in order to understand the basic physiology behind such activity.

\section{Conclusions}

In COPD, dysregulated protease activity results in upregulation of proinflammatory mediators, increased recruitment of inflammatory cells to the lung, inactivation of important innate and antimicrobial proteins resulting in sustained inflammation and destruction of lung tissue. One way to treat such protease-mediated events in COPD is with protease inhibitor therapy. However, the translation of promising protease inhibitors from relevant in vivo models to the clinic has been disappointing thus far. Many clinical trials have focused on the 'short-term' benefits of protease inhibitor treatment but longer-term clinical trials may be required in order to more confidently assess the impact of inhibitor therapy. In addition, due to the presence of multiple protease activities in the COPD lung, it may be important to identify definitively whether there is a key protease or proteases central to direct tissue destruction or activation of other proteases in the diseased lung. Under these circumstances, neutralisation of one such protease with a specific protease inhibitor may lessen the overall protease burden in COPD without the need for multiple inhibitors.

Author Contributions: Original draft preparation: T.D. and C.T.; Review and editing: C.T., J.K. and S.W.

Funding: This research has received the funding from Medical Research Council under the aegis of $\mathrm{MR} / \mathrm{P} 022847 / 1$ grant. 
Acknowledgments: The authors wish to acknowledge funding support from the Medical Research Council (MR/P022847/1— to C.T. and S.W.) and the Medical Research Council Confidence in Concept Scheme (to C.T. and S.W.).

Conflicts of Interest: The authors declare no conflict of interest.

\section{Abbreviations}

\begin{tabular}{|c|c|}
\hline A1AT & $\alpha-1$ antitrypsin \\
\hline Akt & Protein kinase B \\
\hline Bad & Bcl-2-associated death promoter \\
\hline BAL & Broncho alveolar lavage \\
\hline Bax & BCL2-associated $\mathrm{X}$ protein \\
\hline $\mathrm{BbCI}$ & Bauhinia bauhinioide scruzipain inhibitor \\
\hline BmTI-6-D1 & Kunitz-type serine protease inhibitor 6 Recombinant Protein Domain 1 \\
\hline $\mathrm{CB}$ & Chronic bronchitis \\
\hline $\mathrm{CE} / \mathrm{CSE}$ & Cigarette smoke extract \\
\hline COPD & Chronic obstructive pulmonary disease \\
\hline CXCL 12 & C-X-C motif chemokine 12 \\
\hline CXCR1 & C-X-C chemokine receptor type 1 \\
\hline DPP IV & Dipeptidyl peptidase IV \\
\hline eNOS & Endothelial nitric oxide synthases \\
\hline Fc $\gamma$ RIIIb & $\mathrm{Fc} \gamma$ receptor IIIlb \\
\hline $\mathrm{FEV}_{1} / \mathrm{VC}$ & Forced expiratory volume (first second)/vital capacity. \\
\hline $\mathrm{H}_{2} \mathrm{O}_{2}$ & Hydrogen peroxide \\
\hline IFN- $\gamma$ & Interferon gamma \\
\hline IL-1 & Interleukin 1 \\
\hline IL-18 & Interleukin 18 \\
\hline IL-1 $\beta$ & Interleukin 1 beta \\
\hline IL-8 & Interleukin 8 \\
\hline iNOS & Inducible nitric oxide synthase \\
\hline $\mathrm{L}_{\mathrm{m}}$ & Mean linear intercept \\
\hline LPS & Lipopolysaccharide \\
\hline MCP-1 & Monocyte chemoattractant protein 1 \\
\hline MMP & Matrix metalloproteinase \\
\hline $\mathrm{NaHS}$ & Sodium hydrosulfide \\
\hline NE & Neutrophil elastase \\
\hline NLRP3 & NACHT, LRR and PYD domains-containing protein 3 \\
\hline $\mathrm{P} 2 \mathrm{X} 7$ & P2X purinoceptor 7 \\
\hline PAH & Pulmonary arterial hypertension \\
\hline $\mathrm{PF}$ & Pulmonary fibrosis \\
\hline PPE & Porcine pancreatic elastase \\
\hline PR3 & Proteinase 3 \\
\hline rBbKI & recombinant Bauhinia bauhinioides Kallikrein proteinase Inhibitor \\
\hline RLV & Relative lung volumes \\
\hline RVH & Right ventricular hypertrophy \\
\hline SLPI & Secretory leukocyte protease inhibitor \\
\hline Smad & Mothers against decapentaplegic homolog transcription factor \\
\hline TGF- $\beta$ & Transforming growth factor beta 1 \\
\hline $\mathrm{TNF} \alpha$ & Tumor necrosis factor-alpha \\
\hline $\mathrm{V}_{\mathrm{L}}$ & Lung volumes \\
\hline WT-elafin & Wild type elafin \\
\hline
\end{tabular}




\section{References}

1. Lopez, A.D.; Shibuya, K.; Rao, C.; Mathers, C.D.; Hansell, A.L.; Held, L.S.; Schmid, V.; Buist, S. Chronic obstructive pulmonary disease: Current burden and future projections. Eur. Respir. J. 2006, 27, 397-412. [CrossRef] [PubMed]

2. World Health Organization. World Health Organization Report: Burden of Chronic Respiratory Disease; World Health Organization: Geneva, Switzerland, 2011.

3. Dalal, A.A.; Christensen, L.; Liu, F.; Riedel, A.A. Direct costs of chronic obstructive pulmonary disease among managed care patients. Int. J. Chron. Obstr. Pulm. Dis. 2010, 5, 341-349. [CrossRef] [PubMed]

4. Bhome, A.B. COPD in India: Iceberg or volcano? J. Thorac. Dis. 2012, 4, 298-309. [PubMed]

5. Chen, X.; Wang, N.; Chen, Y.; Xiao, T.; Fu, C.; Xu, B. Costs of chronic obstructive pulmonary disease in urban areas of China: A cross-sectional study in four cities. Int. J. Chron. Obstr. Pulm. Dis. 2016, 11, 2625-2632. [CrossRef] [PubMed]

6. Adeloye, D.; Chua, S.; Lee, C.; Basquill, C.; Papana, A.; Theodoratou, E.; Nair, H.; Gasevic, D.; Sridhar, D.; Campbell, H.; et al. Global and regional estimates of COPD prevalence: Systematic review and meta-analysis. J. Glob. Health 2015, 5, 020415. [CrossRef] [PubMed]

7. Nowak, D.; Berger, K.; Lippert, B.; Kilgert, K.; Caeser, M.; Sandtmann, R. Epidemiology and health economics of COPD across Europe: A critical analysis. Treat. Respir. Med. 2005, 4, 381-395. [CrossRef] [PubMed]

8. Lahousse, L.; Seys, L.J.M.; Joos, G.F.; Franco, O.H.; Stricker, B.H.; Brusselle, G.G. Epidemiology and impact of chronic bronchitis in chronic obstructive pulmonary disease. Eur. Respir. J. 2017, 50, 1602470. [CrossRef] [PubMed]

9. Sharafkhaneh, A.; Hanania, N.A.; Kim, V. Pathogenesis of emphysema: From the bench to the bedside. Proc. Am. Thorac. Soc. 2008, 5, 475-477. [CrossRef] [PubMed]

10. Kamal, R.; Srivastava, A.K.; Kesavachandran, C.N. Meta-analysis approach to study the prevalence of chronic obstructive pulmonary disease among current, former and non-smokers. Toxicol. Rep. 2015, 2, 1064-1074. [CrossRef] [PubMed]

11. Tashkin, D.P.; Murray, R.P. Smoking cessation in chronic obstructive pulmonary disease. Respir. Med. 2009, 103, 963-974. [CrossRef] [PubMed]

12. Brode, S.K.; Ling, S.C.; Chapman, K.R. Alpha-1 antitrypsin deficiency: A commonly overlooked cause of lung disease. CMAJ 2012, 184, 1365-1371. [CrossRef] [PubMed]

13. DeMeo, D.L.; Silverman, E.K. Alpha1-antitrypsin deficiency. 2: Genetic aspects of alpha(1)-antitrypsin deficiency: Phenotypes and genetic modifiers of emphysema risk. Thorax 2004, 59, 259-264. [CrossRef] [PubMed]

14. Fukuchi, Y. The aging lung and chronic obstructive pulmonary disease: Similarity and difference. Proc. Am. Thorac. Soc. 2009, 6, 570-572. [CrossRef] [PubMed]

15. Lowery, E.M.; Brubaker, A.L.; Kuhlmann, E.; Kovacs, E.J. The aging lung. Clin. Interv. Aging 2013, 8, 1489-1496. [PubMed]

16. Montuschi, P. Pharmacological treatment of chronic obstructive pulmonary disease. Int. J. Chron. Obstr. Pulm. Dis. 2006, 1, 409-423. [CrossRef]

17. Currie, G.P.; Lipworth, B.J. Inhaled treatment for chronic obstructive pulmonary disease: What's new and how does it fit? QJM Int. J. Med. 2016, 109, 505-512. [CrossRef] [PubMed]

18. Tashkin, D.P.; Ferguson, G.T. Combination bronchodilator therapy in the management of chronic obstructive pulmonary disease. Respir. Res. 2013, 14, 49. [CrossRef] [PubMed]

19. Erkan, L.; Uzun, O.; Findik, S.; Katar, D.; Sanic, A.; Atici, A.G. Role of bacteria in acute exacerbations of chronic obstructive pulmonary disease. Int. J. Chron. Obstr. Pulm. Dis. 2008, 3, 463-467.

20. Beasley, V.; Joshi, P.V.; Singanayagam, A.; Molyneaux, P.L.; Johnston, S.L.; Mallia, P. Lung microbiology and exacerbations in COPD. Int. J. Chron. Obstr. Pulm. Dis. 2012, 7, 555-569.

21. Sethi, S. Bacteria in exacerbations of chronic obstructive pulmonary disease: Phenomenon or epiphenomenon? Proc. Am. Thorac. Soc. 2004, 1, 109-114. [CrossRef] [PubMed]

22. Barnes, P.J. Kinases as novel therapeutic targets in asthma and chronic obstructive pulmonary disease. Pharmacol. Rev. 2016, 68, 788-815. [CrossRef] [PubMed]

23. Page, C.P. Phosphodiesterase inhibitors for the treatment of asthma and chronic obstructive pulmonary disease. Int. Arch. Allergy Immunol. 2014, 165, 152-164. [CrossRef] [PubMed] 
24. Antoniu, S.A. Targeting 5-lipoxygenase-activating protein in asthma and chronic obstructive pulmonary disease. Expert Opin. Ther. Targets 2014, 18, 1285-1292. [CrossRef] [PubMed]

25. Barnes, P.J. New anti-inflammatory targets for chronic obstructive pulmonary disease. Nat. Rev. Drug Discov. 2013, 12, 543-559. [CrossRef] [PubMed]

26. Caruso, M.; Alamo, A.; Crisafulli, E.; Raciti, C.; Fisichella, A.; Polosa, R. Adenosine signaling pathways as potential therapeutic targets in respiratory disease. Expert Opin. Ther. Targets 2013, 17, 761-772. [CrossRef] [PubMed]

27. Drakatos, P.; Lykouras, D.; Sampsonas, F.; Karkoulias, K.; Spiropoulos, K. Targeting leukotrienes for the treatment of COPD? Inflamm. Allergy Drug Targets 2009, 8, 297-306. [CrossRef] [PubMed]

28. Mercer, B.A.; D'Armiento, J.M. Emerging role of map kinase pathways as therapeutic targets in COPD. Int. J. Chron. Obstr. Pulm. Dis. 2006, 1, 137-150. [CrossRef]

29. Bals, R.; Hiemstra, P.S. Antimicrobial peptides in COPD—Basic biology and therapeutic applications. Curr. Drug Targets 2006, 7, 743-750. [CrossRef] [PubMed]

30. Macnee, W.; Rahman, I. Oxidants and antioxidants as therapeutic targets in chronic obstructive pulmonary disease. Am. J. Respir. Crit. Care Med. 1999, 160, S58-S65. [CrossRef] [PubMed]

31. Abboud, R.T.; Vimalanathan, S. Pathogenesis of COPD. Part I. The role of protease-antiprotease imbalance in emphysema. Int. J. Tuberc. Lung Dis. 2008, 12, 361-367. [PubMed]

32. Janciauskiene, S.M.; Bals, R.; Koczulla, R.; Vogelmeier, C.; Kohnlein, T.; Welte, T. The discovery of alpha1-antitrypsin and its role in health and disease. Respir. Med. 2011, 105, 1129-1139. [CrossRef] [PubMed]

33. Bergin, D.A.; Reeves, E.P.; Meleady, P.; Henry, M.; McElvaney, O.J.; Carroll, T.P.; Condron, C.; Chotirmall, S.H.; Clynes, M.; O'Neill, S.J.; et al. Alpha-1 antitrypsin regulates human neutrophil chemotaxis induced by soluble immune complexes and IL-8. J. Clin. Investig. 2010, 120, 4236-4250. [CrossRef] [PubMed]

34. Geraghty, P.; Rogan, M.P.; Greene, C.M.; Brantly, M.L.; O’Neill, S.J.; Taggart, C.C.; McElvaney, N.G. Alpha-1-antitrypsin aerosolised augmentation abrogates neutrophil elastase-induced expression of cathepsin $\mathrm{B}$ and matrix metalloprotease 2 in vivo and in vitro. Thorax 2008, 63, 621-626. [CrossRef] [PubMed]

35. Nadel, J.A. Role of neutrophil elastase in hypersecretion during COPD exacerbations, and proposed therapies. Chest 2000, 117, 386S-389S. [CrossRef] [PubMed]

36. Chang, X.Y.; Yang, Y.; Jia, X.Q.; Wang, Y.; Peng, L.N.; Ai, X.H.; Jiang, C.Y.; Guo, J.H.; Wu, T.T. Expression and clinical significance of serum dipeptidyl peptidase iv chronic obstructive pulmonary disease. Am. J. Med. Sci. 2016, 351, 244-252. [CrossRef] [PubMed]

37. Guyot, N.; Wartelle, J.; Malleret, L.; Todorov, A.A.; Devouassoux, G.; Pacheco, Y.; Jenne, D.E.; Belaaouaj, A. Unopposed cathepsin $\mathrm{G}$, neutrophil elastase, and proteinase 3 cause severe lung damage and emphysema. Am. J. Pathol. 2014, 184, 2197-2210. [CrossRef] [PubMed]

38. Owen, C.A. Roles for proteinases in the pathogenesis of chronic obstructive pulmonary disease. Int. J. Chron. Obstr. Pulm. Dis. 2008, 3, 253-268. [CrossRef]

39. Andersson, C.K.; Mori, M.; Bjermer, L.; Lofdahl, C.G.; Erjefalt, J.S. Alterations in lung mast cell populations in patients with chronic obstructive pulmonary disease. Am. J. Respir. Crit. Care Med. 2010, 181, $206-217$. [CrossRef] [PubMed]

40. Gosman, M.M.; Postma, D.S.; Vonk, J.M.; Rutgers, B.; Lodewijk, M.; Smith, M.; Luinge, M.A.; Ten Hacken, N.H.; Timens, W. Association of mast cells with lung function in chronic obstructive pulmonary disease. Respir. Res. 2008, 9, 64. [CrossRef] [PubMed]

41. Baraldo, S.; Bazzan, E.; Zanin, M.E.; Turato, G.; Garbisa, S.; Maestrelli, P.; Papi, A.; Miniati, M.; Fabbri, L.M.; Zuin, R.; et al. Matrix metalloproteinase-2 protein in lung periphery is related to COPD progression. Chest 2007, 132, 1733-1740. [CrossRef] [PubMed]

42. Hunninghake, G.M.; Cho, M.H.; Tesfaigzi, Y.; Soto-Quiros, M.E.; Avila, L.; Lasky-Su, J.; Stidley, C.; Melen, E.; Soderhall, C.; Hallberg, J.; et al. MMP12, lung function, and COPD in high-risk populations. N. Engl. J. Med. 2009, 361, 2599-2608. [CrossRef] [PubMed]

43. Molet, S.; Belleguic, C.; Lena, H.; Germain, N.; Bertrand, C.P.; Shapiro, S.D.; Planquois, J.M.; Delaval, P.; Lagente, V. Increase in macrophage elastase (MMP-12) in lungs from patients with chronic obstructive pulmonary disease. Inflamm. Res. 2005, 54, 31-36. [CrossRef] [PubMed]

44. Vernooy, J.H.; Lindeman, J.H.; Jacobs, J.A.; Hanemaaijer, R.; Wouters, E.F. Increased activity of matrix metalloproteinase- 8 and matrix metalloproteinase- 9 in induced sputum from patients with COPD. Chest 2004, 126, 1802-1810. [CrossRef] [PubMed] 
45. Lee, E.J.; In, K.H.; Kim, J.H.; Lee, S.Y.; Shin, C.; Shim, J.J.; Kang, K.H.; Yoo, S.H.; Kim, C.H.; Kim, H.K.; et al. Proteomic analysis in lung tissue of smokers and COPD patients. Chest 2009, 135, 344-352. [CrossRef] [PubMed]

46. Papakonstantinou, E.; Karakiulakis, G.; Batzios, S.; Savic, S.; Roth, M.; Tamm, M.; Stolz, D. Acute exacerbations of COPD are associated with significant activation of matrix metalloproteinase 9 irrespectively of airway obstruction, emphysema and infection. Respir. Res. 2015, 16, 78. [CrossRef] [PubMed]

47. Eltom, S.; Belvisi, M.G.; Stevenson, C.S.; Maher, S.A.; Dubuis, E.; Fitzgerald, K.A.; Birrell, M.A. Role of the inflammasome-caspase1/11-IL-1/18 axis in cigarette smoke driven airway inflammation: An insight into the pathogenesis of COPD. PLoS ONE 2014, 9, e112829. [CrossRef] [PubMed]

48. Demedts, I.K.; Demoor, T.; Bracke, K.R.; Joos, G.F.; Brusselle, G.G. Role of apoptosis in the pathogenesis of COPD and pulmonary emphysema. Respir. Res. 2006, 7, 53. [CrossRef] [PubMed]

49. Lockett, A.D.; Van Demark, M.; Gu, Y.; Schweitzer, K.S.; Sigua, N.; Kamocki, K.; Fijalkowska, I.; Garrison, J.; Fisher, A.J.; Serban, K.; et al. Effect of cigarette smoke exposure and structural modifications on the alpha-1 antitrypsin interaction with caspases. Mol. Med. 2012, 18, 445-454. [CrossRef] [PubMed]

50. Podolin, P.L.; Foley, J.P.; Carpenter, D.C.; Bolognese, B.J.; Logan, G.A.; Long, E., III; Harrison, O.J.; Walsh, P.T. $\mathrm{T}$ cell depletion protects against alveolar destruction due to chronic cigarette smoke exposure in mice. Am. J. Physiol. Lung Cell. Mol. Physiol. 2013, 304, L312-L323. [CrossRef] [PubMed]

51. Gogebakan, B.; Bayraktar, R.; Ulasli, M.; Oztuzcu, S.; Tasdemir, D.; Bayram, H. The role of bronchial epithelial cell apoptosis in the pathogenesis of COPD. Mol. Biol. Rep. 2014, 41, 5321-5327. [CrossRef] [PubMed]

52. Kuwano, K.; Yoshimi, M.; Maeyama, T.; Hamada, N.; Yamada, M.; Nakanishi, Y. Apoptosis signaling pathways in lung diseases. Med. Chem. 2005, 1, 49-56. [CrossRef] [PubMed]

53. Kang, M.J.; Homer, R.J.; Gallo, A.; Lee, C.G.; Crothers, K.A.; Cho, S.J.; Rochester, C.; Cain, H.; Chupp, G.; Yoon, H.J.; et al. IL-18 is induced and IL-18 receptor alpha plays a critical role in the pathogenesis of cigarette smoke-induced pulmonary emphysema and inflammation. J. Immunol. 2007, 178, 1948-1959. [CrossRef] [PubMed]

54. Golovatch, P.; Mercer, B.A.; Lemaitre, V.; Wallace, A.; Foronjy, R.F.; D'Armiento, J. Role for cathepsin K in emphysema in smoke-exposed guinea pigs. Exp. Lung Res. 2009, 35, 631-645. [CrossRef] [PubMed]

55. Nakajima, T.; Nakamura, H.; Owen, C.A.; Yoshida, S.; Tsuduki, K.; Chubachi, S.; Shirahata, T.; Mashimo, S.; Nakamura, M.; Takahashi, S.; et al. Plasma cathepsin S and cathepsin S/cystatin C ratios are potential biomarkers for COPD. Dis. Mark. 2016, 2016, 4093870. [CrossRef] [PubMed]

56. Bracke, K.; Cataldo, D.; Maes, T.; Gueders, M.; Noel, A.; Foidart, J.M.; Brusselle, G.; Pauwels, R.A. Matrix metalloproteinase-12 and cathepsin D expression in pulmonary macrophages and dendritic cells of cigarette smoke-exposed mice. Int. Arch. Allergy Immunol. 2005, 138, 169-179. [CrossRef] [PubMed]

57. Zheng, T.; Zhu, Z.; Wang, Z.; Homer, R.J.; Ma, B.; Riese, R.J., Jr.; Chapman, H.A., Jr.; Shapiro, S.D.; Elias, J.A. Inducible targeting of IL-13 to the adult lung causes matrix metalloproteinase- and cathepsin-dependent emphysema. J. Clin. Investig. 2000, 106, 1081-1093. [CrossRef] [PubMed]

58. Cao, W.J.; Li, M.H.; Li, J.X.; Xu, X.; Ren, S.X.; Rajbanshi, B.; Xu, J.F. High expression of cathepsin E is associated with the severity of airflow limitation in patients with COPD. COPD 2016, 13, 160-166. [CrossRef] [PubMed]

59. Zhang, X.; Shan, P.; Homer, R.; Zhang, Y.; Petrache, I.; Mannam, P.; Lee, P.J. Cathepsin E promotes pulmonary emphysema via mitochondrial fission. Am. J. Pathol. 2014, 184, 2730-2741. [CrossRef] [PubMed]

60. Lacy, P. Mechanisms of degranulation in neutrophils. Allergy Asthma Clin. Immunol. 2006, 2, 98-108. [CrossRef] [PubMed]

61. Stockley, R.A. The multiple facets of alpha-1-antitrypsin. Ann. Transl. Med. 2015, 3, 130. [PubMed]

62. Tonelli, A.R.; Brantly, M.L. Augmentation therapy in alpha-1 antitrypsin deficiency: Advances and controversies. Ther. Adv. Respir. Dis. 2010, 4, 289-312. [CrossRef] [PubMed]

63. Higashimoto, Y.; Iwata, T.; Okada, M.; Satoh, H.; Fukuda, K.; Tohda, Y. Serum biomarkers as predictors of lung function decline in chronic obstructive pulmonary disease. Respir. Med. 2009, 103, 1231-1238. [CrossRef] [PubMed]

64. Patel, N.; Belcher, J.; Thorpe, G.; Forsyth, N.R.; Spiteri, M.A. Measurement of c-reactive protein, procalcitonin and neutrophil elastase in saliva of COPD patients and healthy controls: Correlation to self-reported wellbeing parameters. Respir. Res. 2015, 16, 62. [CrossRef] [PubMed]

65. Sng, J.J.; Prazakova, S.; Thomas, P.S.; Herbert, C. MMP-8, MMP-9 and neutrophil elastase in peripheral blood and exhaled breath condensate in COPD. COPD 2017, 14, 238-244. [CrossRef] [PubMed] 
66. Luisetti, M.; Sturani, C.; Sella, D.; Madonini, E.; Galavotti, V.; Bruno, G.; Peona, V.; Kucich, U.; Dagnino, G.; Rosenbloom, J.; et al. MR889, a neutrophil elastase inhibitor, in patients with chronic obstructive pulmonary disease: A double-blind, randomized, placebo-controlled clinical trial. Eur. Respir. J. 1996, 9, 1482-1486. [CrossRef] [PubMed]

67. Kuraki, T.; Ishibashi, M.; Takayama, M.; Shiraishi, M.; Yoshida, M. A novel oral neutrophil elastase inhibitor (ONO-6818) inhibits human neutrophil elastase-induced emphysema in rats. Am. J. Respir. Crit. Care Med. 2002, 166, 496-500. [CrossRef] [PubMed]

68. Wright, J.L.; Farmer, S.G.; Churg, A. Synthetic serine elastase inhibitor reduces cigarette smoke-induced emphysema in guinea pigs. Am. J. Respir. Crit. Care Med. 2002, 166, 954-960. [CrossRef] [PubMed]

69. Kapui, Z.; Varga, M.; Urban-Szabo, K.; Mikus, E.; Szabo, T.; Szeredi, J.; Batori, S.; Finance, O.; Aranyi, P. Biochemical and pharmacological characterization of 2-(9-(2-piperidinoethoxy)-4-oxo-4h-pyrido[1,2a]pyrimidin-2-yloxymethyl)-4-(1-methylethyl)-6-methoxy-1,2-benzisothiazol-3(2h)-one-1,1-dioxide (SSR69071), a novel, orally active elastase inhibitor. J. Pharmacol. Exp. Ther. 2003, 305, 451-459. [CrossRef] [PubMed]

70. Stevens, T.; Ekholm, K.; Granse, M.; Lindahl, M.; Kozma, V.; Jungar, C.; Ottosson, T.; Falk-Hakansson, H.; Churg, A.; Wright, J.L.; et al. AZD9668: Pharmacological characterization of a novel oral inhibitor of neutrophil elastase. J. Pharmacol. Exp. Ther. 2011, 339, 313-320. [CrossRef] [PubMed]

71. Kuna, P.; Jenkins, M.; O’Brien, C.D.; Fahy, W.A. AZD9668, a neutrophil elastase inhibitor, plus ongoing budesonide/formoterol in patients with COPD. Respir. Med. 2012, 106, 531-539. [CrossRef] [PubMed]

72. Vogelmeier, C.; Aquino, T.O.; O’Brien, C.D.; Perrett, J.; Gunawardena, K.A. A randomised, placebo-controlled, dose-finding study of AZD9668, an oral inhibitor of neutrophil elastase, in patients with chronic obstructive pulmonary disease treated with tiotropium. COPD 2012, 9, 111-120. [CrossRef] [PubMed]

73. Martins-Olivera, B.T.; Almeida-Reis, R.; Theodoro-Junior, O.A.; Oliva, L.V.; Neto Dos Santos Nunes, N.; Olivo, C.R.; Vilela de Brito, M.; Prado, C.M.; Leick, E.A.; Martins Mde, A.; et al. The plant-derived Bauhinia bauhinioides kallikrein proteinase inhibitor (rBbKI) attenuates elastase-induced emphysema in mice. Mediat. Inflamm. 2016, 2016, 5346574. [CrossRef] [PubMed]

74. Almeida-Reis, R.; Theodoro-Junior, O.A.; Oliveira, B.T.M.; Oliva, L.V.; Toledo-Arruda, A.C.; Bonturi, C.R.; Brito, M.V.; Lopes, F.; Prado, C.M.; Florencio, A.C.; et al. Plant proteinase inhibitor BbCI modulates lung inflammatory responses and mechanic and remodeling alterations induced by elastase in mice. Biomed. Res. Int. 2017, 2017, 8287125. [CrossRef] [PubMed]

75. Duran, A.F.A.; Neves, L.P.; da Silva, F.R.S.; Machado, G.C.; Ferreira, G.C.; Lourenco, J.D.; Tanaka, A.S.; Martins, M.A.; Lopes, F.; Sasaki, S.D. rBmTI-6 attenuates pathophysiological and inflammatory parameters of induced emphysema in mice. Int. J. Biol. Macromol. 2018, 111, 1214-1221. [CrossRef] [PubMed]

76. Pham, C.T. Neutrophil serine proteases: Specific regulators of inflammation. Nat. Rev. Immunol. 2006, 6, 541-550. [CrossRef] [PubMed]

77. Shafer, W.M.; Pohl, J.; Onunka, V.C.; Bangalore, N.; Travis, J. Human lysosomal cathepsin G and granzyme b share a functionally conserved broad spectrum antibacterial peptide. J. Biol. Chem. 1991, 266, 112-116. [PubMed]

78. Burster, T.; Macmillan, H.; Hou, T.; Boehm, B.O.; Mellins, E.D. Cathepsin G: Roles in antigen presentation and beyond. Mol. Immunol. 2010, 47, 658-665. [CrossRef] [PubMed]

79. Hahn, I.; Klaus, A.; Janze, A.K.; Steinwede, K.; Ding, N.; Bohling, J.; Brumshagen, C.; Serrano, H.; Gauthier, F.; Paton, J.C.; et al. Cathepsin G and neutrophil elastase play critical and nonredundant roles in lung-protective immunity against streptococcus pneumoniae in mice. Infect. Immun. 2011, 79, 4893-4901. [CrossRef] [PubMed]

80. Almansa, R.; Socias, L.; Sanchez-Garcia, M.; Martin-Loeches, I.; del Olmo, M.; Andaluz-Ojeda, D.; Bobillo, F.; Rico, L.; Herrero, A.; Roig, V.; et al. Critical COPD respiratory illness is linked to increased transcriptomic activity of neutrophil proteases genes. BMC Res. Notes 2012, 5, 401. [CrossRef] [PubMed]

81. Barnes, P.J.; Shapiro, S.D.; Pauwels, R.A. Chronic obstructive pulmonary disease: Molecular and cellular mechanisms. Eur. Respir. J. 2003, 22, 672-688. [CrossRef] [PubMed]

82. Sommerhoff, C.P.; Nadel, J.A.; Basbaum, C.B.; Caughey, G.H. Neutrophil elastase and cathepsin G stimulate secretion from cultured bovine airway gland serous cells. J. Clin. Investig. 1990, 85, 682-689. [CrossRef] [PubMed]

83. De Garavilla, L.; Greco, M.N.; Sukumar, N.; Chen, Z.W.; Pineda, A.O.; Mathews, F.S.; Di Cera, E.; Giardino, E.C.; Wells, G.I.; Haertlein, B.J.; et al. A novel, potent dual inhibitor of the leukocyte proteases cathepsin G and chymase: Molecular mechanisms and anti-inflammatory activity in vivo. J. Biol. Chem. 2005, 280, 18001-18007. [CrossRef] [PubMed] 
84. Maryanoff, B.E.; de Garavilla, L.; Greco, M.N.; Haertlein, B.J.; Wells, G.I.; Andrade-Gordon, P.; Abraham, W.M. Dual inhibition of cathepsin $\mathrm{G}$ and chymase is effective in animal models of pulmonary inflammation. Am. J. Respir. Crit. Care Med. 2010, 181, 247-253. [CrossRef] [PubMed]

85. Craciun, I.; Fenner, A.M.; Kerns, R.J. N-arylacyl o-sulfonated aminoglycosides as novel inhibitors of human neutrophil elastase, cathepsin $\mathrm{G}$ and proteinase 3. Glycobiology 2016, 26, 701-709. [CrossRef] [PubMed]

86. Campbell, E.J.; Campbell, M.A.; Owen, C.A. Bioactive proteinase 3 on the cell surface of human neutrophils: Quantification, catalytic activity, and susceptibility to inhibition. J. Immunol. 2000, 165, 3366-3374. [CrossRef] [PubMed]

87. Voswinkel, J.; Muller, A.; Lamprecht, P. Is PR3-anca formation initiated in wegener's granulomatosis lesions? Granulomas as potential lymphoid tissue maintaining autoantibody production. Ann. N. Y. Acad. Sci. 2005, 1051, 12-19. [CrossRef] [PubMed]

88. Sorensen, O.E.; Follin, P.; Johnsen, A.H.; Calafat, J.; Tjabringa, G.S.; Hiemstra, P.S.; Borregaard, N. Human cathelicidin, hcap-18, is processed to the antimicrobial peptide ll-37 by extracellular cleavage with proteinase 3. Blood 2001, 97, 3951-3959. [CrossRef] [PubMed]

89. Coeshott, C.; Ohnemus, C.; Pilyavskaya, A.; Ross, S.; Wieczorek, M.; Kroona, H.; Leimer, A.H.; Cheronis, J. Converting enzyme-independent release of tumor necrosis factor alpha and IL-1beta from a stimulated human monocytic cell line in the presence of activated neutrophils or purified proteinase 3. Proc. Natl. Acad. Sci. USA 1999, 96, 6261-6266. [CrossRef] [PubMed]

90. Sinden, N.J.; Stockley, R.A. Proteinase 3 activity in sputum from subjects with alpha-1-antitrypsin deficiency and COPD. Eur. Respir. J. 2013, 41, 1042-1050. [CrossRef] [PubMed]

91. Janelle, M.F.; Doucet, A.; Bouchard, D.; Bourbonnais, Y.; Tremblay, G.M. Increased local levels of granulocyte colony-stimulating factor are associated with the beneficial effect of pre-elafin (skalp/trappin-2/wap3) in experimental emphysema. Biol. Chem. 2006, 387, 903-909. [CrossRef] [PubMed]

92. Tanga, A.; Saidi, A.; Jourdan, M.L.; Dallet-Choisy, S.; Zani, M.L.; Moreau, T. Protection of lung epithelial cells from protease-mediated injury by trappin-2 a62l, an engineered inhibitor of neutrophil serine proteases. Biochem. Pharmacol. 2012, 83, 1663-1673. [CrossRef] [PubMed]

93. Small, D.M.; Zani, M.L.; Quinn, D.J.; Dallet-Choisy, S.; Glasgow, A.M.; O’Kane, C.; McAuley, D.F.; McNally, P.; Weldon, S.; Moreau, T.; et al. A functional variant of elafin with improved anti-inflammatory activity for pulmonary inflammation. Mol. Ther. 2015, 23, 24-31. [CrossRef] [PubMed]

94. Doucet, A.; Bouchard, D.; Janelle, M.F.; Bellemare, A.; Gagne, S.; Tremblay, G.M.; Bourbonnais, Y. Characterization of human pre-elafin mutants: Full antipeptidase activity is essential to preserve lung tissue integrity in experimental emphysema. Biochem. J. 2007, 405, 455-463. [CrossRef] [PubMed]

95. Tanaka, T.; Camerini, D.; Seed, B.; Torimoto, Y.; Dang, N.H.; Kameoka, J.; Dahlberg, H.N.; Schlossman, S.F.; Morimoto, C. Cloning and functional expression of the T cell activation antigen CD26. J. Immunol. 1992, 149, 481-486. [PubMed]

96. Shubrook, J.; Colucci, R.; Guo, A.; Schwartz, F. Saxagliptin: A selective DPP-4 inhibitor for the treatment of type 2 diabetes mellitus. Clin. Med. Insights Endocrinol. Diabetes 2011, 4, 1-12. [CrossRef] [PubMed]

97. Meyerholz, D.K.; Lambertz, A.M.; McCray, P.B., Jr. Dipeptidyl peptidase 4 distribution in the human respiratory tract: Implications for the middle east respiratory syndrome. Am. J. Pathol. 2016, 186, 78-86. [CrossRef] [PubMed]

98. Somborac-Bacura, A.; Buljevic, S.; Rumora, L.; Culic, O.; Detel, D.; Pancirov, D.; Popovic-Grle, S.; Varljen, J.; Cepelak, I.; Zanic-Grubisic, T. Decreased soluble dipeptidyl peptidase IV activity as a potential serum biomarker for COPD. Clin. Biochem. 2012, 45, 1245-1250. [CrossRef] [PubMed]

99. Seys, L.J.M.; Widagdo, W.; Verhamme, F.M.; Kleinjan, A.; Janssens, W.; Joos, G.F.; Bracke, K.R.; Haagmans, B.L.; Brusselle, G.G. DPP4, the middle east respiratory syndrome coronavirus receptor, is upregulated in lungs of smokers and chronic obstructive pulmonary disease patients. Clin. Infect. Dis. 2018, 66, 45-53. [CrossRef] [PubMed]

100. Herlihy, S.E.; Pilling, D.; Maharjan, A.S.; Gomer, R.H. Dipeptidyl peptidase IV is a human and murine neutrophil chemorepellent. J. Immunol. 2013, 190, 6468-6477. [CrossRef] [PubMed]

101. Busso, N.; Wagtmann, N.; Herling, C.; Chobaz-Peclat, V.; Bischof-Delaloye, A.; So, A.; Grouzmann, E. Circulating CD26 is negatively associated with inflammation in human and experimental arthritis. Am. J. Pathol. 2005, 166, 433-442. [CrossRef] 
102. Herlihy, S.E.; Brown, M.L.; Pilling, D.; Weeks, B.R.; Myers, L.K.; Gomer, R.H. Role of the neutrophil chemorepellent soluble dipeptidyl peptidase iv in decreasing inflammation in a murine model of arthritis. Arthritis Rheumatol. 2015, 67, 2634-2638. [CrossRef] [PubMed]

103. Rohrborn, D.; Eckel, J.; Sell, H. Shedding of dipeptidyl peptidase 4 is mediated by metalloproteases and up-regulated by hypoxia in human adipocytes and smooth muscle cells. FEBS Lett. 2014, 588, 3870-3877. [CrossRef] [PubMed]

104. Payne, V.; Kam, P.C. Mast cell tryptase: A review of its physiology and clinical significance. Anaesthesia 2004, 59, 695-703. [CrossRef] [PubMed]

105. Schwartz, L.B. Tryptase, a mediator of human mast cells. J. Allergy Clin. Immunol. 1990, 86, 594-598. [CrossRef]

106. Peng, Q.; McEuen, A.R.; Benyon, R.C.; Walls, A.F. The heterogeneity of mast cell tryptase from human lung and skin. Eur. J. Biochem. 2003, 270, 270-283. [CrossRef] [PubMed]

107. Kalenderian, R.; Raju, L.; Roth, W.; Schwartz, L.B.; Gruber, B.; Janoff, A. Elevated histamine and tryptase levels in smokers' bronchoalveolar lavage fluid. Do lung mast cells contribute to smokers' emphysema? Chest 1988, 94, 119-123. [CrossRef] [PubMed]

108. Soltani, A.; Ewe, Y.P.; Lim, Z.S.; Sohal, S.S.; Reid, D.; Weston, S.; Wood-Baker, R.; Walters, E.H. Mast cells in COPD airways: Relationship to bronchodilator responsiveness and angiogenesis. Eur. Respir. J. 2012, 39, 1361-1367. [CrossRef] [PubMed]

109. Ballarin, A.; Bazzan, E.; Zenteno, R.H.; Turato, G.; Baraldo, S.; Zanovello, D.; Mutti, E.; Hogg, J.C.; Saetta, M.; Cosio, M.G. Mast cell infiltration discriminates between histopathological phenotypes of chronic obstructive pulmonary disease. Am. J. Respir. Crit. Care Med. 2012, 186, 233-239. [CrossRef] [PubMed]

110. Zhang, X.; Zheng, H.; Ma, W.; Wang, F.; Zeng, X.; Liu, C.; He, S. Tryptase enzyme activity is correlated with severity of chronic obstructive pulmonary disease. Tohoku J. Exp. Med. 2011, 224, 179-187. [CrossRef] [PubMed]

111. Elrod, K.C.; Moore, W.R.; Abraham, W.M.; Tanaka, R.D. Lactoferrin, a potent tryptase inhibitor, abolishes late-phase airway responses in allergic sheep. Am. J. Respir. Crit. Care Med. 1997, 156, 375-381. [CrossRef] [PubMed]

112. Krishna, M.T.; Chauhan, A.; Little, L.; Sampson, K.; Hawksworth, R.; Mant, T.; Djukanovic, R.; Lee, T.; Holgate, S. Inhibition of mast cell tryptase by inhaled APC 366 attenuates allergen-induced late-phase airway obstruction in asthma. J. Allergy Clin. Immunol. 2001, 107, 1039-1045. [CrossRef] [PubMed]

113. Oh, S.W.; Pae, C.I.; Lee, D.K.; Jones, F.; Chiang, G.K.; Kim, H.O.; Moon, S.H.; Cao, B.; Ogbu, C.; Jeong, K.W.; et al. Tryptase inhibition blocks airway inflammation in a mouse asthma model. J. Immunol. 2002, 168, 1992-2000. [CrossRef] [PubMed]

114. Ishizaki, M.; Tanaka, H.; Kajiwara, D.; Toyohara, T.; Wakahara, K.; Inagaki, N.; Nagai, H. Nafamostatmesilate, a potent serine protease inhibitor, inhibits airway eosinophilic inflammation and airway epithelial remodeling in a murine model of allergic asthma. J. Pharmacol. Sci. 2008, 108, 355-363. [CrossRef] [PubMed]

115. Caughey, G.H. Mast cell tryptases and chymases in inflammation and host defense. Immunol. Rev. 2007, 217, 141-154. [CrossRef] [PubMed]

116. Wang, T.; Han, S.X.; Zhang, S.F.; Ning, Y.Y.; Chen, L.; Chen, Y.J.; He, G.M.; Xu, D.; An, J.; Yang, T.; et al. Role of chymase in cigarette smoke-induced pulmonary artery remodeling and pulmonary hypertension in hamsters. Respir. Res. 2010, 11, 36. [CrossRef] [PubMed]

117. Wypij, D.M.; Nichols, J.S.; Novak, P.J.; Stacy, D.L.; Berman, J.; Wiseman, J.S. Role of mast cell chymase in the extracellular processing of big-endothelin-1 to endothelin-1 in the perfused rat lung. Biochem. Pharmacol. 1992, 43, 845-853. [CrossRef]

118. Tchougounova, E.; Lundequist, A.; Fajardo, I.; Winberg, J.O.; Abrink, M.; Pejler, G. A key role for mast cell chymase in the activation of pro-matrix metalloprotease-9 and pro-matrix metalloprotease-2. J. Biol. Chem. 2005, 280, 9291-9296. [CrossRef] [PubMed]

119. Karlson, U.; Pejler, G.; Froman, G.; Hellman, L. Rat mast cell protease 4 is a beta-chymase with unusually stringent substrate recognition profile. J. Biol. Chem. 2002, 277, 18579-18585. [CrossRef] [PubMed]

120. Amin, K. The role of mast cells in allergic inflammation. Respir. Med. 2012, 106, 9-14. [CrossRef] [PubMed]

121. Kosanovic, D.; Dahal, B.K.; Peters, D.M.; Seimetz, M.; Wygrecka, M.; Hoffmann, K.; Antel, J.; Reiss, I.; Ghofrani, H.A.; Weissmann, N.; et al. Histological characterization of mast cell chymase in patients with pulmonary hypertension and chronic obstructive pulmonary disease. Pulm. Circ. 2014, 4, 128-136. [CrossRef] [PubMed] 
122. Kosanovic, D.; Luitel, H.; Dahal, B.K.; Cornitescu, T.; Janssen, W.; Danser, A.H.; Garrelds, I.M.; De Mey, J.G.; Fazzi, G.; Schiffers, P.; et al. Chymase: A multifunctional player in pulmonary hypertension associated with lung fibrosis. Eur. Respir. J. 2015, 46, 1084-1094. [CrossRef] [PubMed]

123. He, S.H.; Zheng, J. Stimulation of mucin secretion from human bronchial epithelial cells by mast cell chymase. Acta Pharmacol. Sin. 2004, 25, 827-832. [PubMed]

124. Tinel, H.; Zubov, D.; Zimmermann, K.; Tersteegen, A.; Boerngen, K.; Joerissen, H.; Ackerstaff, J.; Fuerstner, C. Abstract 13624: A novel chymase inhibitor bay 1142524 reduces fibrosis and improves cardiac function after myocardial infarction in hamster. Circulation 2017, 136, A13624.

125. Bot, I.; Bot, M.; van Heiningen, S.H.; van Santbrink, P.J.; Lankhuizen, I.M.; Hartman, P.; Gruener, S.; Hilpert, H.; van Berkel, T.J.; Fingerle, J.; et al. Mast cell chymase inhibition reduces atherosclerotic plaque progression and improves plaque stability in ApoE-/ - mice. Cardiovasc. Res. 2011, 89, 244-252. [CrossRef] [PubMed]

126. Miyaoka, Y.; Jin, D.; Tashiro, K.; Komeda, K.; Masubuchi, S.; Hirokawa, F.; Hayashi, M.; Takai, S.; Uchiyama, K. Chymase inhibitor prevents the development and progression of non-alcoholic steatohepatitis in rats fed a high-fat and high-cholesterol diet. J. Pharmacol. Sci. 2017, 134, 139-146. [CrossRef] [PubMed]

127. Singh, D.; Srivastava, S.K.; Chaudhuri, T.K.; Upadhyay, G. Multifaceted role of matrix metalloproteinases (MMPs). Front. Mol. Biosci. 2015, 2, 19. [CrossRef] [PubMed]

128. Gueders, M.M.; Foidart, J.M.; Noel, A.; Cataldo, D.D. Matrix metalloproteinases (MMPs) and tissue inhibitors of MMPs in the respiratory tract: Potential implications in asthma and other lung diseases. Eur. J. Pharmacol. 2006, 533, 133-144. [CrossRef] [PubMed]

129. Elkington, P.T.; Friedland, J.S. Matrix metalloproteinases in destructive pulmonary pathology. Thorax 2006, 61, 259-266. [CrossRef] [PubMed]

130. D'Armiento, J.; Dalal, S.S.; Okada, Y.; Berg, R.A.; Chada, K. Collagenase expression in the lungs of transgenic mice causes pulmonary emphysema. Cell 1992, 71, 955-961. [CrossRef]

131. Mercer, P.F.; Shute, J.K.; Bhowmik, A.; Donaldson, G.C.; Wedzicha, J.A.; Warner, J.A. MMP-9, TIMP-1 and inflammatory cells in sputum from COPD patients during exacerbation. Respir. Res. 2005, 6, 151. [CrossRef] [PubMed]

132. Ilumets, H.; Rytila, P.; Demedts, I.; Brusselle, G.G.; Sovijarvi, A.; Myllarniemi, M.; Sorsa, T.; Kinnula, V.L. Matrix metalloproteinases-8, -9 and -12 in smokers and patients with stage 0 COPD. Int. J. Chron. Obstr. Pulm. Dis. 2007, 2, 369-379.

133. Brajer, B.; Batura-Gabryel, H.; Nowicka, A.; Kuznar-Kaminska, B.; Szczepanik, A. Concentration of matrix metalloproteinase- 9 in serum of patients with chronic obstructive pulmonary disease and a degree of airway obstruction and disease progression. J. Physiol. Pharmacol. 2008, 59 (Suppl. 6), 145-152. [PubMed]

134. Selman, M.; Cisneros-Lira, J.; Gaxiola, M.; Ramirez, R.; Kudlacz, E.M.; Mitchell, P.G.; Pardo, A. Matrix metalloproteinases inhibition attenuates tobacco smoke-induced emphysema in guinea pigs. Chest 2003, 123, 1633-1641. [CrossRef] [PubMed]

135. Pemberton, P.A.; Cantwell, J.S.; Kim, K.M.; Sundin, D.J.; Kobayashi, D.; Fink, J.B.; Shapiro, S.D.; Barr, P.J. An inhaled matrix metalloprotease inhibitor prevents cigarette smoke-induced emphysema in the mouse. COPD 2005, 2, 303-310. [CrossRef] [PubMed]

136. Ma, D.; Jiang, Y.; Chen, F.; Gong, L.K.; Ding, K.; Xu, Y.; Wang, R.; Ge, A.; Ren, J.; Li, J.; et al. Selective inhibition of matrix metalloproteinase isozymes and in vivo protection against emphysema by substituted gamma-keto carboxylic acids. J. Med. Chem. 2006, 49, 456-458. [CrossRef] [PubMed]

137. Churg, A.; Wang, R.; Wang, X.; Onnervik, P.O.; Thim, K.; Wright, J.L. Effect of an MMP-9/MMP-12 inhibitor on smoke-induced emphysema and airway remodelling in guinea pigs. Thorax 2007, 62, 706-713. [CrossRef] [PubMed]

138. Dahl, R.; Titlestad, I.; Lindqvist, A.; Wielders, P.; Wray, H.; Wang, M.; Samuelsson, V.; Mo, J.; Holt, A. Effects of an oral MMP-9 and -12 inhibitor, AZD1236, on biomarkers in moderate/severe COPD: A randomised controlled trial. Pulm. Pharmacol. Ther. 2012, 25, 169-177. [CrossRef] [PubMed]

139. Kim, S.E.; Thanh Thuy, T.T.; Lee, J.H.; Ro, J.Y.; Bae, Y.A.; Kong, Y.; Ahn, J.Y.; Lee, D.S.; Oh, Y.M.; Lee, S.D.; et al. Simvastatin inhibits induction of matrix metalloproteinase-9 in rat alveolar macrophages exposed to cigarette smoke extract. Exp. Mol. Med. 2009, 41, 277-287. [CrossRef] [PubMed] 
140. Sun, J.; Bao, J.; Shi, Y.; Zhang, B.; Yuan, L.; Li, J.; Zhang, L.; Sun, M.; Sun, W. Effect of simvastatin on MMPs and TIMPs in cigarette smoke-induced rat COPD model. Int. J. Chron. Obstr. Pulm. Dis. 2017, 12, 717-724. [CrossRef] [PubMed]

141. Perng, D.W.; Tao, C.W.; Su, K.C.; Tsai, C.C.; Liu, L.Y.; Lee, Y.C. Anti-inflammatory effects of salmeterol/fluticasone, tiotropium/fluticasone or tiotropium in COPD. Eur. Respir. J. 2009, 33, 778-784. [CrossRef] [PubMed]

142. Kasahara, Y.; Tuder, R.M.; Taraseviciene-Stewart, L.; Le Cras, T.D.; Abman, S.; Hirth, P.K.; Waltenberger, J.; Voelkel, N.F. Inhibition of VEGF receptors causes lung cell apoptosis and emphysema. J. Clin. Investig. 2000, 106, 1311-1319. [CrossRef] [PubMed]

143. Kasahara, Y.; Tuder, R.M.; Cool, C.D.; Lynch, D.A.; Flores, S.C.; Voelkel, N.F. Endothelial cell death and decreased expression of vascular endothelial growth factor and vascular endothelial growth factor receptor 2 in emphysema. Am. J. Respir. Crit. Care Med. 2001, 163, 737-744. [CrossRef] [PubMed]

144. Aoshiba, K.; Yokohori, N.; Nagai, A. Alveolar wall apoptosis causes lung destruction and emphysematous changes. Am. J. Respir. Cell. Mol. Biol. 2003, 28, 555-562. [CrossRef] [PubMed]

145. Yokohori, N.; Aoshiba, K.; Nagai, A. Increased levels of cell death and proliferation in alveolar wall cells in patients with pulmonary emphysema. Chest 2004, 125, 626-632. [CrossRef] [PubMed]

146. Imai, K.; Mercer, B.A.; Schulman, L.L.; Sonett, J.R.; D'Armiento, J.M. Correlation of lung surface area to apoptosis and proliferation in human emphysema. Eur. Respir. J. 2005, 25, 250-258. [CrossRef] [PubMed]

147. Hodge, S.; Hodge, G.; Holmes, M.; Reynolds, P.N. Increased airway epithelial and T-cell apoptosis in COPD remains despite smoking cessation. Eur. Respir. J. 2005, 25, 447-454. [CrossRef] [PubMed]

148. Couillin, I.; Vasseur, V.; Charron, S.; Gasse, P.; Tavernier, M.; Guillet, J.; Lagente, V.; Fick, L.; Jacobs, M.; Coelho, F.R.; et al. IL-1R1/MyD88 signaling is critical for elastase-induced lung inflammation and emphysema. J. Immunol. 2009, 183, 8195-8202. [CrossRef] [PubMed]

149. Eltom, S.; Stevenson, C.S.; Rastrick, J.; Dale, N.; Raemdonck, K.; Wong, S.; Catley, M.C.; Belvisi, M.G.; Birrell, M.A. P2X7 receptor and caspase 1 activation are central to airway inflammation observed after exposure to tobacco smoke. PLoS ONE 2011, 6, e24097. [CrossRef] [PubMed]

150. Chen, Y.; Hanaoka, M.; Droma, Y.; Chen, P.; Voelkel, N.F.; Kubo, K. Endothelin-1 receptor antagonists prevent the development of pulmonary emphysema in rats. Eur. Respir. J. 2010, 35, 904-912. [CrossRef] [PubMed]

151. Yoshida, M.; Nakayama, K.; Yasuda, H.; Kubo, H.; Kuwano, K.; Arai, H.; Yamaya, M. Carbocisteine inhibits oxidant-induced apoptosis in cultured human airway epithelial cells. Respirology 2009, 14, 1027-1034. [CrossRef] [PubMed]

152. Hanaoka, M.; Droma, Y.; Chen, Y.; Agatsuma, T.; Kitaguchi, Y.; Voelkel, N.F.; Kubo, K. Carbocisteine protects against emphysema induced by cigarette smoke extract in rats. Chest 2011, 139, 1101-1108. [CrossRef] [PubMed]

153. Han, W.; Dong, Z.; Dimitropoulou, C.; Su, Y. Hydrogen sulfide ameliorates tobacco smoke-induced oxidative stress and emphysema in mice. Antioxid. Redox Signal. 2011, 15, 2121-2134. [CrossRef] [PubMed]

154. Zhang, L.; Guo, X.; Xie, W.; Li, Y.; Ma, M.; Yuan, T.; Luo, B. Resveratrol exerts an anti-apoptotic effect on human bronchial epithelial cells undergoing cigarette smoke exposure. Mol. Med. Rep. 2015, 11, 1752-1758. [CrossRef] [PubMed]

155. Zheng, T.; Kang, M.J.; Crothers, K.; Zhu, Z.; Liu, W.; Lee, C.G.; Rabach, L.A.; Chapman, H.A.; Homer, R.J.; Aldous, D.; et al. Role of cathepsin S-dependent epithelial cell apoptosis in IFN-gamma-induced alveolar remodeling and pulmonary emphysema. J. Immunol. 2005, 174, 8106-8115. [CrossRef] [PubMed]

156. Saetta, M.; Di Stefano, A.; Turato, G.; Facchini, F.M.; Corbino, L.; Mapp, C.E.; Maestrelli, P.; Ciaccia, A.; Fabbri, L.M. CD8+ T-lymphocytes in peripheral airways of smokers with chronic obstructive pulmonary disease. Am. J. Respir. Crit. Care Med. 1998, 157, 822-826. [CrossRef] [PubMed]

157. Lams, B.E.; Sousa, A.R.; Rees, P.J.; Lee, T.H. Subepithelial immunopathology of the large airways in smokers with and without chronic obstructive pulmonary disease. Eur. Respir. J. 2000, 15, 512-516. [CrossRef] [PubMed]

158. Grumelli, S.; Corry, D.B.; Song, L.Z.; Song, L.; Green, L.; Huh, J.; Hacken, J.; Espada, R.; Bag, R.; Lewis, D.E.; et al. An immune basis for lung parenchymal destruction in chronic obstructive pulmonary disease and emphysema. PLoS Med. 2004, 1, e8. [CrossRef] [PubMed]

159. O'Shaughnessy, T.C.; Ansari, T.W.; Barnes, N.C.; Jeffery, P.K. Inflammation in bronchial biopsies of subjects with chronic bronchitis: Inverse relationship of CD8+ T lymphocytes with FEV1. Am. J. Respir. Crit. Care Med. 1997, 155, 852-857. [CrossRef] [PubMed] 
160. Wang, Z.; Zheng, T.; Zhu, Z.; Homer, R.J.; Riese, R.J.; Chapman, H.A., Jr.; Shapiro, S.D.; Elias, J.A. Interferon gamma induction of pulmonary emphysema in the adult murine lung. J. Exp. Med. 2000, 192, 1587-1600. [CrossRef] [PubMed]

161. Geraghty, P.; Greene, C.M.; O’Mahony, M.; O’Neill, S.J.; Taggart, C.C.; McElvaney, N.G. Secretory leucocyte protease inhibitor inhibits interferon-gamma-induced cathepsin S expression. J. Biol. Chem. 2007, 282, 33389-33395. [CrossRef] [PubMed]

162. Buhling, F.; Gerber, A.; Hackel, C.; Kruger, S.; Kohnlein, T.; Bromme, D.; Reinhold, D.; Ansorge, S.; Welte, T. Expression of cathepsin K in lung epithelial cells. Am. J. Respir. Cell. Mol. Biol. 1999, 20, 612-619. [CrossRef] [PubMed]

163. Barrett, A.J. Cathepsin D. Purification of isoenzymes from human and chicken liver. Biochem. J. 1970, 117, 601-607. [CrossRef] [PubMed]

164. Mizuochi, T.; Yee, S.T.; Kasai, M.; Kakiuchi, T.; Muno, D.; Kominami, E. Both cathepsin B and cathepsin $\mathrm{D}$ are necessary for processing of ovalbumin as well as for degradation of class II mhc invariant chain. Immunol. Lett. 1994, 43, 189-193. [CrossRef]

165. Diment, S.; Martin, K.J.; Stahl, P.D. Cleavage of parathyroid hormone in macrophage endosomes illustrates a novel pathway for intracellular processing of proteins. J. Biol. Chem. 1989, 264, 13403-13406. [PubMed]

166. Khalkhali-Ellis, Z.; Abbott, D.E.; Bailey, C.M.; Goossens, W.; Margaryan, N.V.; Gluck, S.L.; Reuveni, M.; Hendrix, M.J. IFN-gamma regulation of vacuolarph, cathepsin D processing and autophagy in mammary epithelial cells. J. Cell. Biochem. 2008, 105, 208-218. [CrossRef] [PubMed]

167. Zaidi, N.; Kalbacher, H. Cathepsin E: A mini review. Biochem. Biophys. Res. Commun. 2008, 367, 517-522. [CrossRef] [PubMed]

168. Keliher, E.J.; Reiner, T.; Earley, S.; Klubnick, J.; Tassa, C.; Lee, A.J.; Ramaswamy, S.; Bardeesy, N.; Hanahan, D.; Depinho, R.A.; et al. Targeting cathepsin E in pancreatic cancer by a small molecule allows in vivo detection. Neoplasia 2013, 15, 684-693. [CrossRef] [PubMed]

169. Kawakubo, T.; Yasukochi, A.; Toyama, T.; Takahashi, S.; Okamoto, K.; Tsukuba, T.; Nakamura, S.; Ozaki, Y.; Nishigaki, K.; Yamashita, H.; et al. Repression of cathepsin E expression increases the risk of mammary carcinogenesis and links to poor prognosis in breast cancer. Carcinogenesis 2014, 35, 714-726. [CrossRef] [PubMed]

170. Konno-Shimizu, M.; Yamamichi, N.; Inada, K.; Kageyama-Yahara, N.; Shiogama, K.; Takahashi, Y.; Asada-Hirayama, I.; Yamamichi-Nishina, M.; Nakayama, C.; Ono, S.; et al. Cathepsin E is a marker of gastric differentiation and signet-ring cell carcinoma of stomach: A novel suggestion on gastric tumorigenesis. PLoS ONE 2013, 8, e56766. [CrossRef] [PubMed]

(C) 2018 by the authors. Licensee MDPI, Basel, Switzerland. This article is an open access article distributed under the terms and conditions of the Creative Commons Attribution (CC BY) license (http:/ / creativecommons.org/licenses/by/4.0/). 